\title{
REDE DE DRENAGEM URBANA EM ÁREA TROPICAL: MUDAN- ÇAS NA MORFOLOGIA DO CANAL E NÍVEIS DE POLUIÇÃO DAS ÁGUAS - RIO DOS MACACOS - RIO DE JANEIRO - RJ
}

\author{
Luciano Marin Lucas* \\ $\&$ \\ Sandra Baptista Cunha**
}

\section{RESUMO:}

O presente trabalho, realizado na área urbana da cidade do Rio de Janeiro, teve como objetivo analisar as variações ocorridas na morfologia do canal do rio dos Macacos, bem como avaliar os níveis de poluição das águas ao longo do perfil longitudinal, em virtude da atuação antrópica. A área de estudo foi monitorada no período de março de 2002 a fevereiro de 2003. As mudanças na morfologia foram identificadas através da relação entre as variáveis obtidas em campo, como largura, profundidade, área da seção transversal, raio hidráulico e relação largura/profundidade (L/P). Para a avaliação dos níveis de poluição das águas do canal foram feitas interpretações dos valores obtidos dos parâmetros pH, OD, DBO e colimetria. No período estudado, as maiores variações na morfologia foram identificadas na área das seções transversais, onde ocorreu a erosão do canal (aumento da capacidade do canal de até $0,28 \mathrm{~m}^{2}$ no PT1) e o assoreamento acentuado identificado através da redução do canal de até $0,90 \mathrm{~m}^{2}$ no PT5. Quanto ao nível de poluição da água, foram identificados índices extremamente elevados de coliformes fecais de até $1.600 .000 \mathrm{NMP} / 100 \mathrm{ml}$ para todos os pontos, enquanto que, valores reduzidos de OD e DBO foram identificados próximos a jusante, provenientes da maior concentração de efluentes.

\section{PALAVRAS-CHAVE:}

Geomorfologia fluvial; canais urbanos; rio dos Macacos; qualidade da água; atuação antrópica.

\section{ABSTRACT:}

The present work, accomplished in the urban area of the city of Rio de Janeiro, aimed to analyze the variation occurred in the morphology of Macacos river channel. The levels of pollution in the waters along the longitudinal profile was also evaluated due to human actuation. The area was monitored from March 2002 until February 2003. The changes in the morphology were identified through the relation among variables obteined in field, as width, depth, cross-sectional area, hydraulic ray and relation width/depth (W/D). In order to evaluate the levels of pollution in the waters of the channel some interpretation of the obtained values from parameters $\mathrm{pH}, \mathrm{DO}, \mathrm{BOD}$ and colimetry were performed. In the studied period, the largest variation in the morphology were identified in the cross-sections area where occurred the erosion of the channel (which increased the channel capacity to $0,28 \mathrm{~m}^{2}$ in PT1) and high deposition identified through the reduction of the channel to $0,90 \mathrm{~m}^{2}$ in PT5. Regarding to the level of water pollution, extremely high rates of fecal coliform were identified (1.600.00 NMP/100 ml for all the points), whereas reduced values of DO and BOD were identified next to downstream, due to the largest effluent concentration.

\section{KEY WORDS:}

Fluvial geomorphology, urban channels, Macacos river, water quality, human actuation. 


\section{I- Introdução}

O interesse pelo reconhecimento das características dos canais fluviais tem crescido em todo o mundo, principalmente a partir de quando o homem, como agente modelador da paisagem, passou a interferir na dinâmica e forma dos canais. A importância dos rios não reside somente no fato destes serem um dos agentes geológicos mais expressivos no modelado da superfície terrestre, mas também por se apresentarem como um condicionante ambiental da própria vida do homem (SUGUIO e BIGARELLA, 1990).

Desde os primórdios, as civilizações antigas prosperavam às margens dos rios, buscando conhecer sua dinâmica para fins de navegação e abastecimento de água. Hoje, cerca de $80 \%$ da população do Brasil encontra-se nos grandes centros urbanos, ocasionando uma super ocupação do espaço que, associado à falta de conscientização quanto a importância dos ambientes fluviais na vida do homem, gera a deterioração destes ambientes.

Uma das principais conseqüências são as enchentes, provenientes da ineficácia do canal em transportar um grande volume d'água, devido muito vezes, ao assoreamento do leito, gerado pelo aumento do transporte de sedimentos e de lixo para o canal, oriundo das áreas impermeáveis. Além disso, casos típicos, como a poluição das águas, também podem ser observados, em que os canais recebem diariamente efluentes domésticos e industriais, bem como resíduos sólidos (lixo), comprometendo o ecossistema ali presente.

As mudanças em uma bacia hidrográfica ou em um canal podem variar sob influência do processo de urbanização, estabelecendo-se novas condições de equilíbrio. Essas mudanças registram-se de acordo com a escala temporal, podendo ocorrer ao longo do tempo geológico ou em um curto prazo (WOLMAN, 1967). Segundo o autor, o processo ou ciclo de urbanização de uma bacia, que é refletido no canal, consiste em três fases: a inicial - estável ou condição de equilíbrio, cuja paisagem caracteriza-se pela agricultura e florestas; a de construção - na qual a terra apresentase nua e exposta à erosão; e a final - em que prevalece uma nova paisagem impermeável dominada por ruas, residências, indústrias, edificações, etc.

O conhecimento das características fluviais é importante não somente para o entendimento da morfologia e dinâmica dos canais, mas também como pré-requisito para uma proposta de recuperação e planejamento destes ambientes (PERRONE e BARROSO, 1996). O surgimento de problemas ambientais graves, com reflexos sobre o próprio homem, o levou a melhor compreender os fenômenos naturais e a entender que deve agir como parte integrante do sistema natural. Esta conscientização, entretanto, ainda não alcançou uma parcela significativa da população, que continua a provocar mudanças drásticas nos ecossistemas, alterando-os de forma a prejudicar seus componentes, entre eles o próprio homem (MOTA, 1997).

Problemáticas como as inundações e a poluição das águas são resultados do manejo inadequado dos recursos naturais, no qual o processo de ocupação do espaço prioriza os interesses políticos e econômicos, degradando o meio ambiente e diminuindo a qualidade de vida (CUNHA e GUERRA, 1996). Portanto, não somente estudos científicos expressivos devem ser desenvolvidos nestes ambientes mas, também, é necessária a participação da sociedade, através da conscientização do uso racional dos recursos, para que a resposta da natureza sobre as ações antrópicas não traga danos ainda maiores a população.

Para PORTO et al. (1997), as melhores 
Rede de drenagem urbana em área tropical: mudanças na morfologia do canal

soluções para estes problemas são obtidas a partir de uma compreensão integrada do ambiente urbano. O conceito de drenagem urbana não mais se restringe a engenharia mas engloba também a um problema gerencial, com componentes políticos e sociais.

Estudos integrados com equipes interdisciplinares, que conheçam os vários processos atuantes em um problema, são mais eficazes, devido a complexidade ambiental em que estão inseridos os ambientes urbanos. Considerando-se a grande quantidade de ambientes degradados e a crescente necessidade de água potável, torna-se essencial a caracterização dos impactos nos rios. Estudos não menos importantes, como os de restauração dos ecossistemas degradados, e propostas de diminuição do impacto, levando em consideração as relações socioeconômicas, garantem o processo de modernização sem degradar o meio ambiente, através do desenvolvimento sustentável (MUEHE e VALENTINI, 1998).

Pensando nisso, a Secretaria Municipal de Meio Ambiente da Cidade do Rio

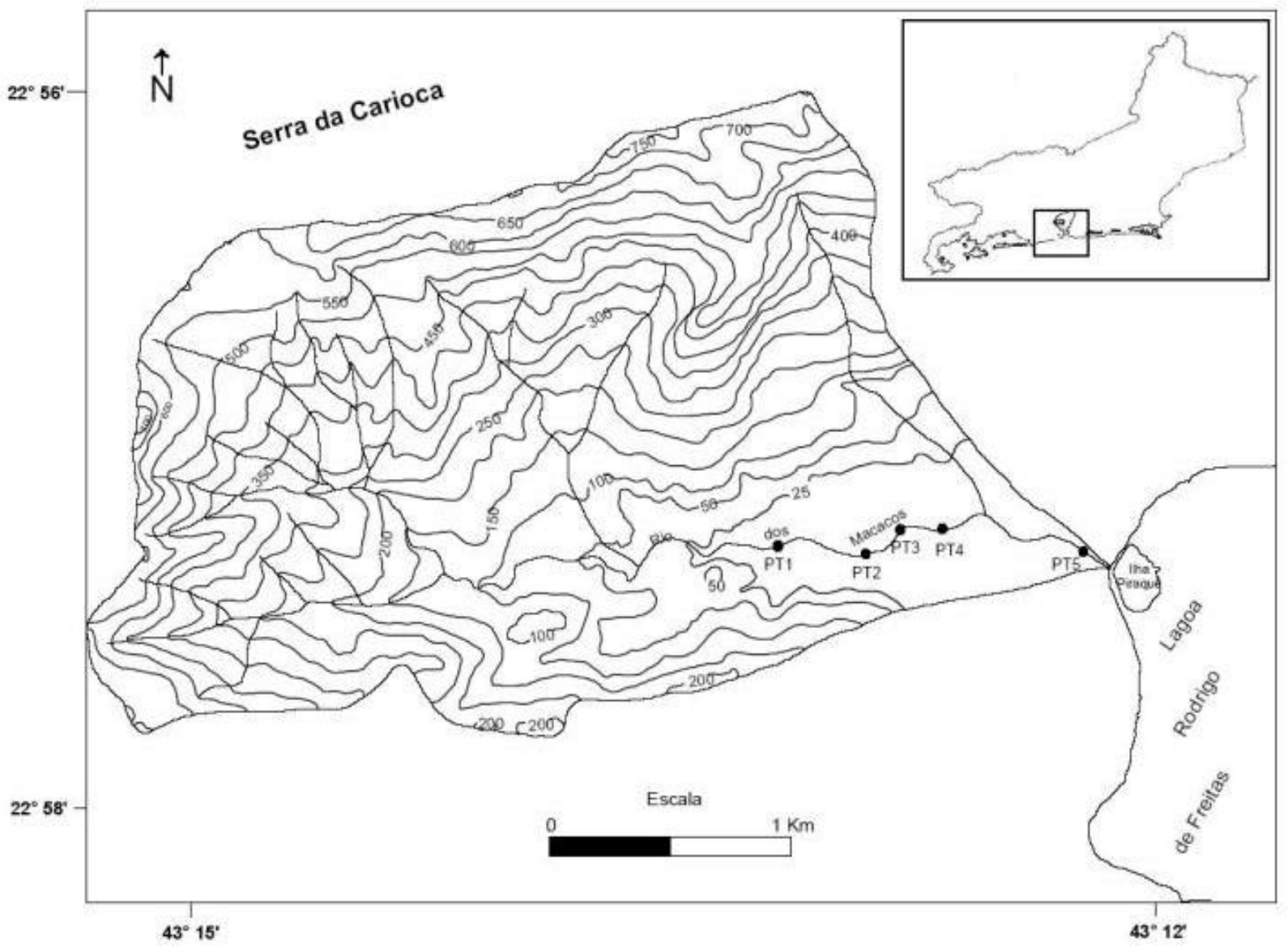

Figura 1 - Localização do rio dos Macacos 
de Janeiro implantou o projeto denominado "Guardiões dos Rios" que consiste na contratação de moradores de baixa renda das comunidades ribeirinhas, tendo como objetivo principal o monitoramento e a limpeza sistemática em mais de 50 rios do Município. A contribuição deste trabalho é de extrema importância, pois com a presença constante dos guardiões é possível estar informado sobre as mudanças que ocorrem no canal como variação da vazão, fontes de poluição e quantidade de resíduos sólidos retirados do leito e das margens do canal.

Estudos geomorfológicos que envolvam o reconhecimento, a análise (quantitativa e qualitativa) e a avaliação dos canais podem fornecer informações importantes sobre a forma e os processos físicos atuantes no sistema fluvial (THORNE et al., 1996). Desta maneira, a adaptação de estudos desenvolvidos em regiões temperadas para regiões tropicais podem trazer soluções alternativas para a manutenção do canal, de modo que ele possa recuperar parte de suas características naturais.

Este trabalho, realizado entre o período de março (2002) e fevereiro (2003), teve como objetivos identificar as mudanças ocorridas na morfologia e no comportamento sedimentológico do canal do rio dos Macacos (RJ), bem como avaliar os níveis de poluição de suas águas, devido a atuação antrópica, com a finalidade de buscar alternativas para a recuperação das características naturais do canal e do ecossistema, contribuindo para a gestão do mesmo.

A área em questão compreende o rio dos Macacos $(4,81 \mathrm{~km})$, incluindo seus afluentes (riacho do Pai Ricardo, rio Algodão, rio Cabeça e rio Rainha), localizados na cidade do Rio de Janeiro (Figura 1). Suas nascentes estão situadas na vertente sul do maciço da Tijuca, drenando suas águas para a lagoa Rodrigo de Freitas. Para facilidade de análise, o rio dos Macacos foi dividido em setores ( $A, B$ e C) por apresentar características distintas observadas em campo quanto a morfologia e aos níveis de poluição das águas ao longo do canal (Figura 2).

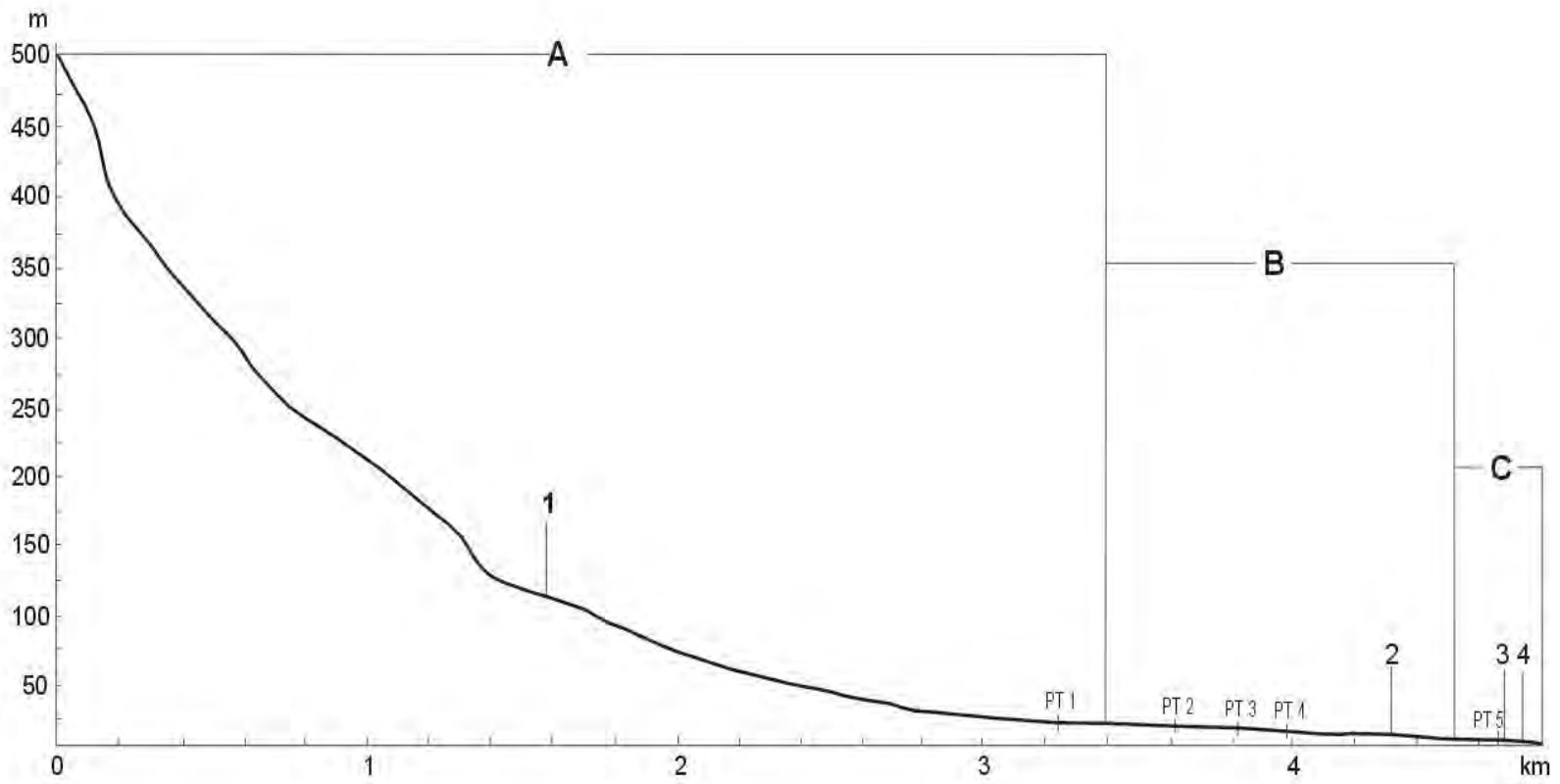

Figura 2 - Perfil Longitudinal do rio dos Macacos identificando a confluência com: (1) riacho do Pai Ricardo, (2) rio Algodão, (3) rio Cabeça e (4) rio Rainha. (A), (B) e (C) - setores do canal. Os pontos PT1, PT2, PT3, PT4 e PT5 indicam os locais de amostragem. 
Rede de drenagem urbana em área tropical: mudanças na morfologia do canal

\section{II- Aspectos Gerais da Área}

A bacia do rio dos Macacos está inserida no maciço da Tijuca, composto por rochas cristalinas do complexo Paraíba do Sul (SERLA, 1990). As rochas predominantes são os gnaisses e migmatitos altamente tectonizados, provenientes de esforços compressivos no sentido SE-NW ocorridos no pré-cambriano inferior a médio.

Durante o pré-cambriano médio e superior ocorreram intrusões graníticas, compostas por uma diversidade de rochas, predominando os granitos pós-tectônicos de estrutura fluidal, evidenciada pela orientação das palhetas de biotita. As rochas básicas (basalto e diabásio) são provenientes de intrusões ocorridas no cretácio-jurássico, dispostas em forma de diques discordantes em várias direções (SERLA, 1990). De modo geral, o canal segue uma linha de falha com direção W-L e desenvolve seu vale em relevo dobrado formado por rochas cristalinas e diques de diabásio (EMBRAPA, 1992). Os sedimentos como cascalhos, areias e siltes inconsolidados, provenientes do intemperismo destas rochas, encontram-se na calha do rio que, através do fluxo da água, os transporta para a Lagoa Rodrigo de Freitas.

A bacia do rio dos Macacos encontra-se inserida na unidade morfológica maciços costeiros, representada pela serra da Carioca. Nas encostas é possível observar os depósitos originados pelo transporte por gravidade e que se intensificam em períodos de chuva intensa. A evolução desses processos resulta na planície interiorana com pouca variação de declividade, variando com relação ao assoreamento e a deposição de sedimentos transportados pelo rio. Os solos originados dos processos erosivos consistem em latossolos, nas regiões de menor inclinação e neossolos e cambissolos nas regiões onde a inclinação é mais acentuada (EMBRAPA, 1999).

As médias anuais de precipitação variam entre $1.500 \mathrm{~mm}$ e $2.500 \mathrm{~mm}$ (COSTA, 1995). De acordo com BRANDÃO (1997), nos últimos anos, o aumento da atuação do homem sobre o ambiente fez com que a intensidade e a freqüência das chuvas, no município do Rio de Janeiro, se elevasse. O crescente aumento urbano traz como conseqüência a redução das áreas verdes, o que contribui para a aceleração dos processos erosivos, fornecendo maior quantidade de sedimentos para os canais, assoreamento e intensificando as inundações.

Frente a pluviosidade observa-se reduzida capacidade de armazenamento da água pelos solos que cobrem os pontos mais altos da bacia (nascente) por causa da sua fina espessura. Sendo assim, apenas uma pequena parcela da água fica retida no solo enquanto que a maior parte escoa pela superfície até os rios (afluentes e principal), provocando os regimes de cheia.

Em períodos de pouca ou nula pluviosidade ocorre uma diminuição da vazão, uma vez que o escoamento superficial, que é o principal responsável pelo fornecimento de volume de água para o canal, apresenta-se praticamente nulo. Assim, o rio passa a ser alimentado apenas pelos reservatórios subterrâneos.

Nos pontos mais baixos, onde o gradiente do canal apresenta pouca variação, o escoamento superficial ainda é o principal responsável pela contribuição hídrica para o canal, pois estas áreas apresentam-se densamente ocupadas e modificadas pela atuação antrópica. Como conseqüência deste processo ocorre a impermeabilização do solo, impossibilitando a infiltração da água.

O rio dos Macacos possui uma extensão de $4,81 \mathrm{~km}$, podendo ser separado em setores ( $A, B$ e C), de acordo com suas características morfológicas e em relação aos níveis de poluição das águas (Figura 2):

Setor A - localiza-se entre as cotas de 500 e $20 \mathrm{~m}$ de altitude, com uma extensão de $3,41 \mathrm{~km}$. Nesse setor, a elevada variação do gradiente justifica a forma do vale em $\mathrm{V}$, onde $\mathrm{o}$ 
processo de entalhamento do talvegue e a produção de sedimentos ocorre de forma mais expressiva, por causa do aumento da energia do fluxo. As margens são compostas por blocos rochosos e mata ciliar, ao passo que o leito apresenta grande quantidade de seixos e matacões, bem como, areias e matéria orgânica. Nesse trecho pode-se observar a expansão de favelas de forma desordenada, sendo a população ocupa a margem do canal, utilizando o rio como local de depósito de lixo e de lançamento direto de esgoto doméstico. Outro fator ainda mais agravante refere-se ao lançamento de produtos industriais provenientes de uma lavanderia, comprometendo a qualidade e o aspecto da água.

Setor $B$ - Corresponde ao trecho do rio dentro do Jardim Botânico, com uma extensão de $1,12 \mathrm{~km}$ e entre as cotas de 20 e $5 \mathrm{~m}$ de altitude, em que o canal apresenta a ampliação da calha e do fundo do vale em razão da diminuição da declividade. As obras de canalização, utilizando blocos rochosos para a proteção das margens, tiveram início no 1 o Reinado quando, em 1824, foram feitos vários aterros nas margens. No 20 Reinado foram aterradas áreas próximas ao canal e deu-se início ao processo de retificação e desvios de parte do mesmo (EMBRAPA, 1992). Desde então, o canal vem sofrendo modificações devido à falta de manutenção dos blocos encaixados, os quais constituem as margens e que, com o tempo, estão sendo erodidos, permitindo que caiam no leito do rio.

Os sedimentos caracterizam-se pela maior quantidade de areia e seixos de menor calibre que os encontrados no setor anterior e que passam a se acumular no leito do rio. Ainda neste setor, é possível observar o lançamento de efluentes domésticos no canal e em seus afluentes (rio Algodão), provenientes de edifícios próximos ao Jardim Botânico.

Setor C - Inicia-se na cota de $5 \mathrm{~m}$ de altitude até desaguar na lagoa Rodrigo de Freitas sobre a cota de $2 \mathrm{~m}$. Com um trecho de
$0,28 \mathrm{~km}$, as margens e o fundo do leito foram alterados por obras de engenharia mais recentes, através da concretagem que, associadas às chuvas concentradas e as respostas imediatas da vazão, acentuam os problemas de inundação local. É possível observar a formação de bancos de areia e assoreamento no leito, em razão da diminuição da capacidade de fluxo, associado ao baixo gradiente de declividade.

Neste setor, não só o lançamento de esgoto pode ser observado, como também o escoamento pluvial que, em períodos de chuva, contribui para a poluição do canal, através do transporte de detritos e lixo. As águas apresentam coloração escura, devido ao esgoto, ao lixo e aos sedimentos em suspensão.

\section{III- Condicionantes Climáticos, hidrológicos e antrópicos.}

\section{III.I- Análise dos dados pluviométricos}

Para a análise das variações na morfologia do canal, fez-se necessário obter os valores diários e totais mensais de precipitação dos meses de janeiro de 2002 a fevereiro de 2003, da Estação Climatológica Auxiliar do Jardim Botânico (Figura 3). Em termos de totais pluviométricos, a precipitação anual registrada no período foi de $2.054 \mathrm{~mm}$

Os meses mais chuvosos foram novembro de 2002 (356mm) e janeiro de 2003 $(360 \mathrm{~mm})$. Este fato está relacionado à maior distribuição de chuvas que ocorreram em 19 dias do mês de janeiro enquanto que em novembro a precipitação mais expressiva ocorreu de forma concentrada entre os dias 06 e $07(103,4 \mathrm{~mm}$ e $122 \mathrm{~mm}$ ) (Tabela 1$)$.

As chuvas constantes ao longo do mês de janeiro, com destaque para as precipitações registradas entre os dias 25, 26 e $27(54,8 \mathrm{~mm}$, $32,4 \mathrm{~mm}$ e $92,3 \mathrm{~mm}$, respectivamente), foram as principais responsáveis pelas maiores modificações na morfologia ao longo do canal, de acordo com o observado no trabalho de campo realizado em 10/02/03. 


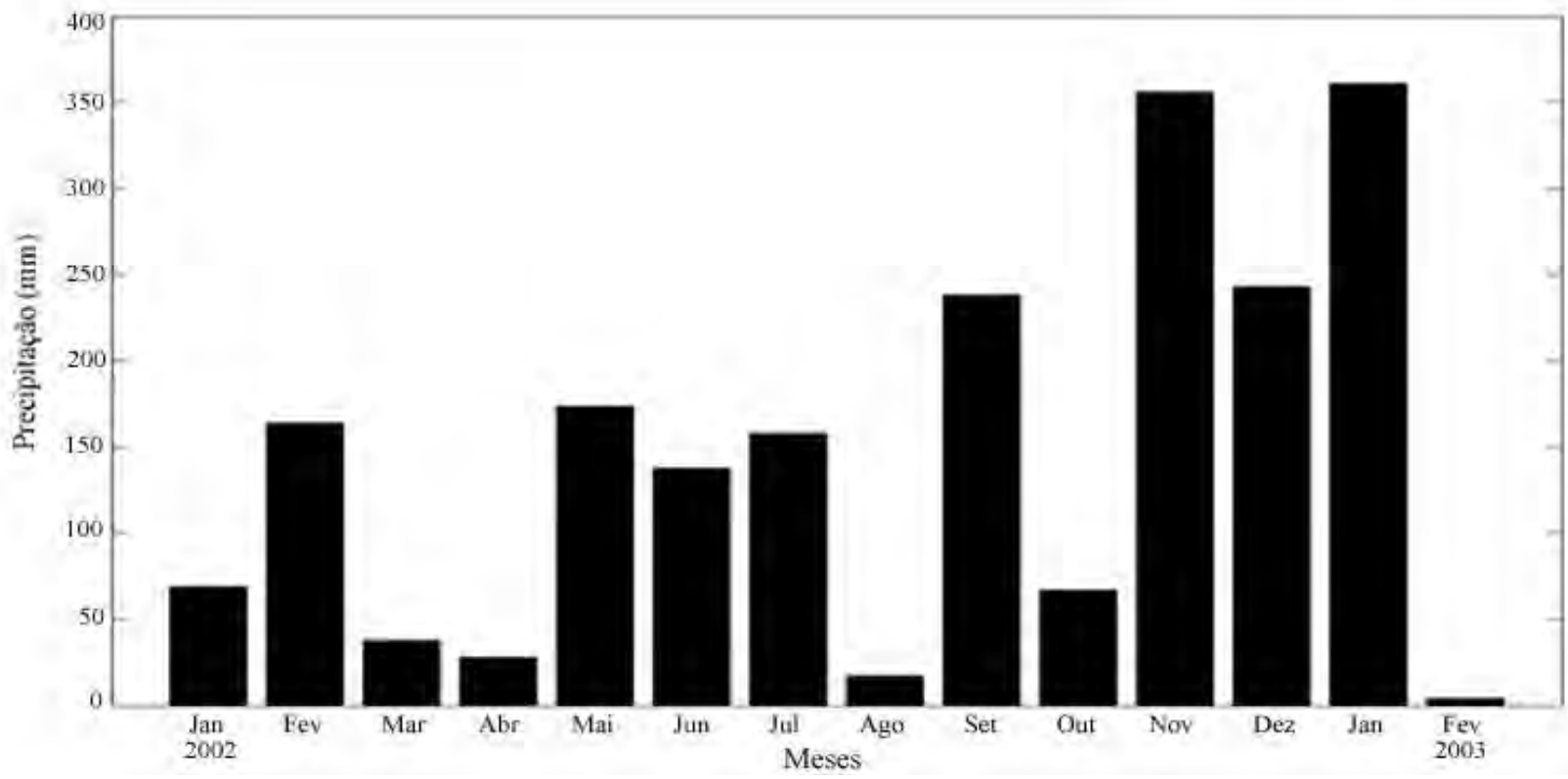

Figura 3 - Totais mensais de precipitação entre os meses de janeiro de 2002 e fevereiro de 2003. Fonte: Instituto Nacional de Meteorologia (INMET) / Sexto Distrito de Meteorologia (6o DISME)

Tabela 1 - Precipitaçóes em 24 horas, superiones a $50 \mathrm{~mm}$, registradas na Estação Climatológica Ausiliar do Jardim Botânico (janeiro de 2002 a feverairo de 2003).

\begin{tabular}{|c|c|}
\hline Data & Precipitação diária em (m m) \\
\hline 03 Fey. 2002 & 58,2 \\
\hline 23 Jun. 2002 & $\mathbf{1 0 3 , 2}$ \\
\hline 12 Jul. 2002 & 68,4 \\
\hline 25 Set. 2002 & 90,4 \\
\hline $\mathbf{0 6}$ Nov. 2002 & $\mathbf{1 0 3 , 4}$ \\
\hline 07 Nov. 2002 & $\mathbf{1 2 2 , 0}$ \\
\hline 19 Nav.2002 & 79,2 \\
\hline 10 Dez.2002 & 90,2 \\
\hline 25.Jan.2003 & $\mathbf{5 4 , 8}$ \\
\hline 27 Jan. 2003 & $\mathbf{9 2 , 3}$ \\
\hline
\end{tabular}

Fonte: Instituto Nacional de Meteorologia (INMET) / Sexto Distrito de Meteorologia ( $6^{\circ}$ DISME) 


\section{III.II- Parâmetros da morfodinâmica do canal}

O processo de urbanização, decorrente do desenvolvimento urbano, reflete diretamente nas características físicas dos canais fluviais, trazendo como resultado o processo de erosão, assoreamento e diminuição na capacidade do canal, bem como, o aumento da precipitação e impermeabilização do solo. Mudanças ocorridas nas bacias de drenagem podem ter causas naturais, entretanto, nos últimos anos, o homem tem atuado como um agente acelerador dos processos modificadores e de desequilíbrios da paisagem (CUNHA e GUERRA, 1996).

Segundo EBISEMIJU (1989) os impactos da atividade humana sobre o meio ambiente podem ser de dois tipos: diretos e indiretos. Porém, os mais significativos são os indiretos, originados pela urbanização, que envolve as mudanças no uso da terra, na rede de canais, na precipitação e temperatura, na criação de superfícies impermeáveis, na propriedade e estrutura do solo e exposição da superfície do solo através do desmatamento.

Ao estudar a região de Ado-Ekiti, um dos principais centros urbanos da Nigéria, o autor identificou que, a exceção de duas bacias intensamente cultivadas, os canais de bacias rurais estão em equilíbrio. Contudo, os canais das bacias urbanizadas apresentam graus variados de desequilíbrio, dado pelas diferenças na distribuição e grau de urbanização, bem como, na intensificação de construções mais recentes, que resulta em variações na capacidade e eficiência do canal.

$$
\text { As mudanças climáticas e }
$$
antropogenéticas são semelhantes nos termos de seus impactos nos sistemas geomorfológicos, por serem relativamente rápidas em comparação com mudanças em outros sistemas ambientais (GRAFF, 1978). Para o autor, os dois tipos de mudanças afetam os sistemas fluviais pela modificação da vegetação e da superfície da terra, o que, conseqüentemente, afeta os regimes hidrológicos, alterando a morfologia e dinâmica do canal.
As variações em modelos de descarga dos canais fluviais refletem as características da bacia de drenagem, as condições climáticas e as atividades humanas. A atenção é cada vez maior para os efeitos do uso da terra na modificação do escoamento superficial e para os impactos diretos sobre o canal como a regulação para melhorar a drenagem, reduzir as inundações, e controlar a erosão das margens. O aumento de superfícies impermeáveis, geradas pelo processo de urbanização, leva ao aumento do escoamento superficial e a rápida remoção da água da chuva de áreas em construção, acarretando o aumento da descarga do canal (WHITLOW e GREGORY, 1989). Para o autor, que desenvolveu sua pesquisa no Zimbabwe (área tropical), as conclusões foram de que houve uma diminuição das áreas alagadiças por causa do crescimento urbano e da introdução de seções descontínuas no curso do canal que ligam as áreas alagadas.

Para GREGORY et al. (1992) o conhecimento de como as mudanças nos canais fluviais no presente, passado e futuro ocorrem no meio ambiente e, particularmente, em relação aos impactos da atividade humana, são necessários para o entendimento das relações entre forma do canal e processos atuantes. Pesquisas realizadas no final do século mostram a natureza das mudanças ocorridas no canal em conseqüência do crescimento urbano: regulação do fluxo, canalização e mudanças no uso da terra.

Ao estudar o riacho dos Monges, no centro-sul da Inglaterra, GREGORY (op. cit.) identificou um aumento considerável na média da largura do canal, a jusante da área urbana, relacionado ao aumento do fluxo. Em algumas seções transversais o desenvolvimento de obstáculos mostrou uma redução na capacidade e largura do canal, evidenciando um ajustamento da geometria proveniente da atividade humana.

No estudo aqui proposto, a morfologia do canal foi analisada em duas dimensões: transversal e longitudinal. A dimensão 
Rede de drenagem urbana em área tropical: mudanças na morfologia do canal

e níveis de poluição das águas - Rio dos Macacos - Rio de Janeiro - RJ, pp. 39 - 64

\begin{tabular}{|c|c|c|c|c|c|c|c|c|c|}
\hline & Latgura & Prol. do & Prol. Media & Area & Rate & Vei. Max. & vei. Med. & Vazáo & पP \\
\hline \multirow[t]{2}{*}{ PTI } & & Talvegue & & & Hadrifulico & & & & \\
\hline & $m$ & $\mathrm{~m}$ & $m$ & $m^{2}$ & $m$ & $\mathrm{~m} / \mathrm{s}$ & $m / s$ & $m / s$ & $m$ \\
\hline $28 / 03 / 02$ & 4.70 & 2.65 & 2.46 & 11.56 & 0.17 & 0.53 & 0.33 & 0.25 & 1.91 \\
\hline $14 / 05702$ & 4.70 & 2.69 & 2.47 & 11.61 & 0.15 & 0.65 & 0.35 & 0.23 & 1.90 \\
\hline 10707002 & 4.70 & 2.82 & 2.51 & 11.80 & 0.13 & 0.92 & $0.5 E$ & 0.27 & 1.87 \\
\hline ज्ञा0902 & 4.70 & 2.83 & 2.52 & 11.84 & 0.19 & 1.29 & 0.96 & 0.50 & 1.87 \\
\hline $15 / 11 / 02$ & $4.70^{-}$ & 2.80 & 2.52 & 11.84 & 0.13 & 0.85 & 0.85 & 0.44 & 1.87 \\
\hline \multirow[t]{2}{*}{$10 / 02 / 03$} & 4.70 & 2.80 & 2.52 & 11.84 & 0.16 & 0,70 & 0,70 & 0.46 & 1.87 \\
\hline & Gingura & Prol.du & Prer. MEda & Areta & $\operatorname{Ran}$ & vel. Max. & vel. Med. & Vaso & Wp \\
\hline \multirow[t]{2}{*}{ PT2 } & & 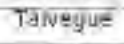 & & & Hedraties & & & & 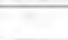 \\
\hline & $\pi$ & $m$ & $\pi$ & $m^{2}$ & $m$ & $\pi / 5$ & $\pi / s$ & $m+5$ & $\pi$ \\
\hline 2a/03/02 & 4.35 & 1.97 & 1.90 & 8.27 & 0.08 & 0.43 & 0.38 & 0.13 & 2.29 \\
\hline $16 / 255 / 02$ & 4.35 & 1.95 & 1.91 & 8.31 & 0.15 & 0.43 & 0.32 & 0.26 & 2.28 \\
\hline $10 / 07 / 02$ & 4.35 & 1.95 & 1.91 & 8.31 & 0.14 & 0.53 & 0.34 & 0.21 & 2.28 \\
\hline (x)0S/02 & 4.35 & 1.97 & 1.92 & 8.35 & 0.10 & 0.25 & 0.19 & 0.08 & 2.27 \\
\hline $15 / 11 / 02$ & 4.35 & 2.00 & 1.95 & 8.48 & 0.23 & 0.25 & 0.25 & 0,27 & 2.23 \\
\hline \multirow[t]{2}{*}{$10 / 02 / 01$} & 4.35 & 1.99 & 1.95 & 8.48 & 0.28 & 0.78 & 0.78 & 1.05 & 2.23 \\
\hline & Largura & Prot. do & Prol, Média & Area & Raía & Vel, Max. & Vel, MEd. & Vazaq & प्रP \\
\hline \multirow[t]{2}{*}{ PT3 } & & Talvegue & & & Hadrauhos & & & & \\
\hline & $\pi$ & $m$ & $m$ & $m^{2}$ & $m$ & $\pi / 5$ & $\pi / s$ & {$[\pi / s$} & in \\
\hline $29 / 01 / 02$ & 5.05 & 2.70 & 1.60 & 8.08 & 0.09 & 0,95 & 0.75 & 0.26 & 3.16 \\
\hline $14 / 05 / 02$ & 5.05 & 1.68 & 1.55 & 7.88 & 0.19 & 0.73 & 0.81 & 0.25 & 3.24 \\
\hline $10 / 01 / 02$ & 5.05 & 1.68 & $1.5 ?$ & 7.93 & 0.11 & D. 86 & $0 . M$ & 0.30 & 3.22 \\
\hline ब1/09/02 & 5.05 & 1.71 & 1.56 & 2.98 & 0.11 & 0.46 & 0.33 & 0.10 & 3.20 \\
\hline $15 / 11 / 02$ & 5.05 & 1.68 & 1.5 & 7.78 & 0.20 & 0,43 & 0,43 & 0.26 & 3.28 \\
\hline \multirow[t]{2}{*}{$10 / 02703$} & 5.05 & 1.80 & 1.55 & 7.83 & 0.27 & 0.65 & 0.65 & 0.62 & 3.26 \\
\hline & Largura & Prol. des & Prol. Media & Area & Raio & vel. Max. & vel. Mél. & Vade & जए \\
\hline \multirow[t]{2}{*}{ PT4 } & & Talyegue & & & Radrifulice & & & & \\
\hline & in & mi & $m$ & $\operatorname{trn}^{2}$ & $m$ & $m / s$ & $m / s$ & $m^{1} / 9$ & in \\
\hline $28 / 03 / 02$ & 4.18 & 1.45 & 1.39 & 5.81 & 0.25 & 0.33 & 0.21 & 0.24 & 3.01 \\
\hline $14 / 05702$ & 4.18 & 1.51 & 1.41 & 5.89 & 0.21 & 0.30 & 0.15 & 0.14 & 2.96 \\
\hline 10707002 & 4.18 & 1.50 & 1.45 & 5.98 & 0.22 & 0.15 & 0.25 & 0.24 & 2.92 \\
\hline DI/KG/O2 & 4.18 & 1.48 & 1,35 & 5.64 & 0.19 & 0.17 & 0.15 & 0.13 & 3.10 \\
\hline $15 / 11 / 02$ & 4.18 & 1.50 & 1.40 & 5.85 & 0.28 & $0.1 \%$ & 0.1 र & 0.21 & 2.99 \\
\hline \multirow[t]{2}{*}{10802703} & 4.18 & 1.63 & 1.37 & 5.73 & 0.29 & 0.35 & 0.35 & 0,50 & 3.05 \\
\hline & Largura & Prol, od & Prol. Média & Area & Rand & vel. Max. & vel. Med. & Vazio & $4 p$ \\
\hline \multirow[t]{2}{*}{ PTS } & - & Talvegue & & & Hidraticos & & & & \\
\hline & $\pi$ & $\pi$ & m & $\pi^{2}$ & in & $\pi / s$ & $\pi / s$ & $m^{2} / 5$ & III \\
\hline $24 / 03 / 02$ & 10.00 & 2.48 & 1.7 & 17.70 & 0.94 & 0.13 & 0.15 & 0.77 & 5.65 \\
\hline $14 / 05 / 02$ & 10.00 & 2.50 & 1.78 & 17.80 & 1.00 & 0.25 & 0.15 & 0.83 & 5.62 \\
\hline 10007702 & 10.00 & 2.45 & 1.28 & 17.80 & 0.86 & 0.20 & 0.15 & 0.69 & 5.62 \\
\hline (1709/02 & 10,00 & 2.48 & 1.79 & 17.90 & 1.09 & 0,10 & 0.10 & 0.63 & 5.59 \\
\hline $15 / 11 / 02$ & 10.00 & 2.40 & 1.77 & 17.70 & 1.12 & 0.09 & 0.09 & 0,61 & 5.65 \\
\hline $10 / 02 / 03$ & 10.00 & 2.28 & 1.68 & 16.80 & 0.27 & 0.66 & 0.86 & 1.03 & 5.95 \\
\hline
\end{tabular}

Tabela 2 - Variáveis da morfodinâmica do canal. 
longitudinal consistiu em integrar os setores longitudinalmente, das nascentes até a desembocadura na Lagoa Rodrigo de Freitas. A dimensão transversal foi obtida através da relação entre as variáveis largura e profundidades do canal, medidas em campo entre os períodos de março de 2002 e fevereiro de 2003. Os valores obtidos foram plotados no software Excel $^{\circledR}$, para a confecção dos perfis transversais, facilitando a análise e comparação dos dados.

Os resultados obtidos, com relação às mudanças ocorridas na geometria do canal do rio dos Macacos, foram analisados e discutidos por setores através da comparação dos dados de cada seção transversal.

\section{Setor $A$ - (PT1)}

O perfil transversal traçado no ponto PT1 apresentou valores constantes de largura $(4,70 \mathrm{~m})$ e valores irregulares de profundidade do talvegue entre 2,65 e $2,83 \mathrm{~m}$ (Tabela 2 ). Nos 13 meses monitorados, a área da seção transversal aumentou gradativamente, passando de 11,56 para $11,84 \mathrm{~m}^{2}$, evidenciando o processo de entalhamento e erosão do leito. Neste ponto, a declividade e o fundo rochoso caracterizam o fluxo turbulento que é o principal responsável pelo aumento nos valores da profundidade média e da área da seção transversal. A água que percola por entre as rochas ganha mais intensidade, concentrandose apenas em alguns trechos do canal, e não em toda a extensão do leito. A velocidade média apresentou valores elevados entre 0,33 e $0,96 \mathrm{~m} / \mathrm{s}$, enquanto que os valores de vazão variaram entre 0,23 e $0,50 \mathrm{~m}^{3} / \mathrm{s}$.

Poucos metros abaixo deste ponto, em direção à jusante, é possível observar o processo de solapamento de base das margens compostas por blocos rochosos encaixados que, pelo intenso fluxo derivado dos períodos de maior precipitação, acabam caindo no leito do canal (Figura 4).

Os valores de raio hidráulico oscilaram de forma irregular, entre 0,13 e 0,19m, evidenciando a baixa eficiência do canal quanto ao escoamento do fluxo. Este fato está associado a rugosidade do leito, composto por blocos e matacões, que dificultam a passagem da água.

O aumento nos valores da relação largura/profundidade (L/P), de 1,87 a 1,91m, evidenciam a erosão do leito e caracterizam o canal como profundo e estreito (Figura 5).

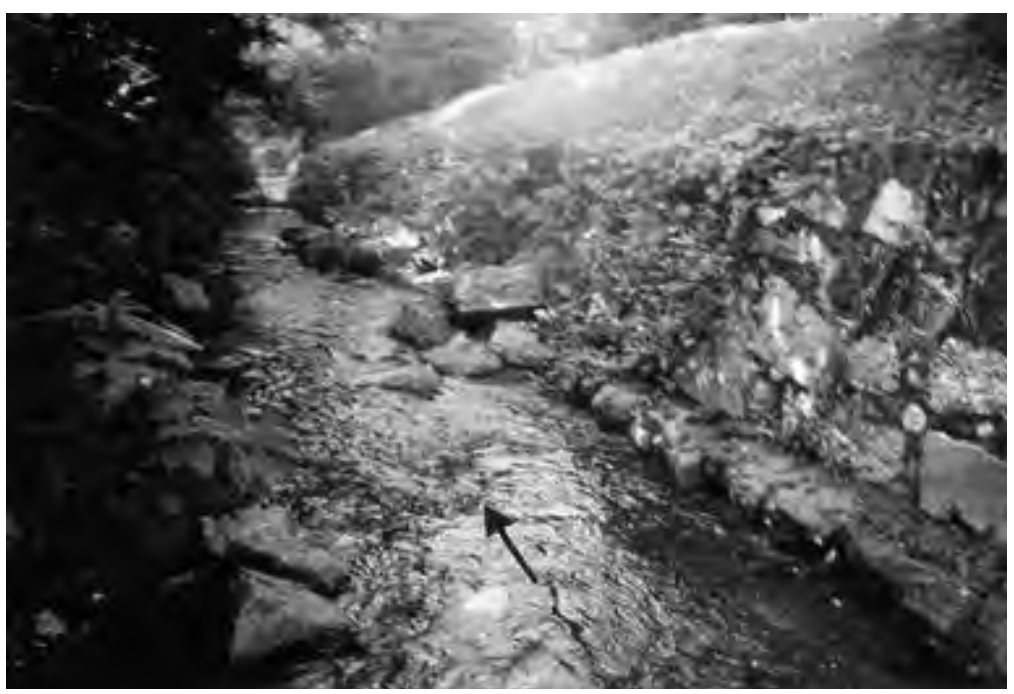

Figura 4 - Processo de erosão de base, à jusante do PT1, evidenciado pelos blocos deslocados no leito do canal (Foto: maio de 2003, Crédito: L. Lucas). 
Rede de drenagem urbana em área tropical: mudanças na morfologia do canal
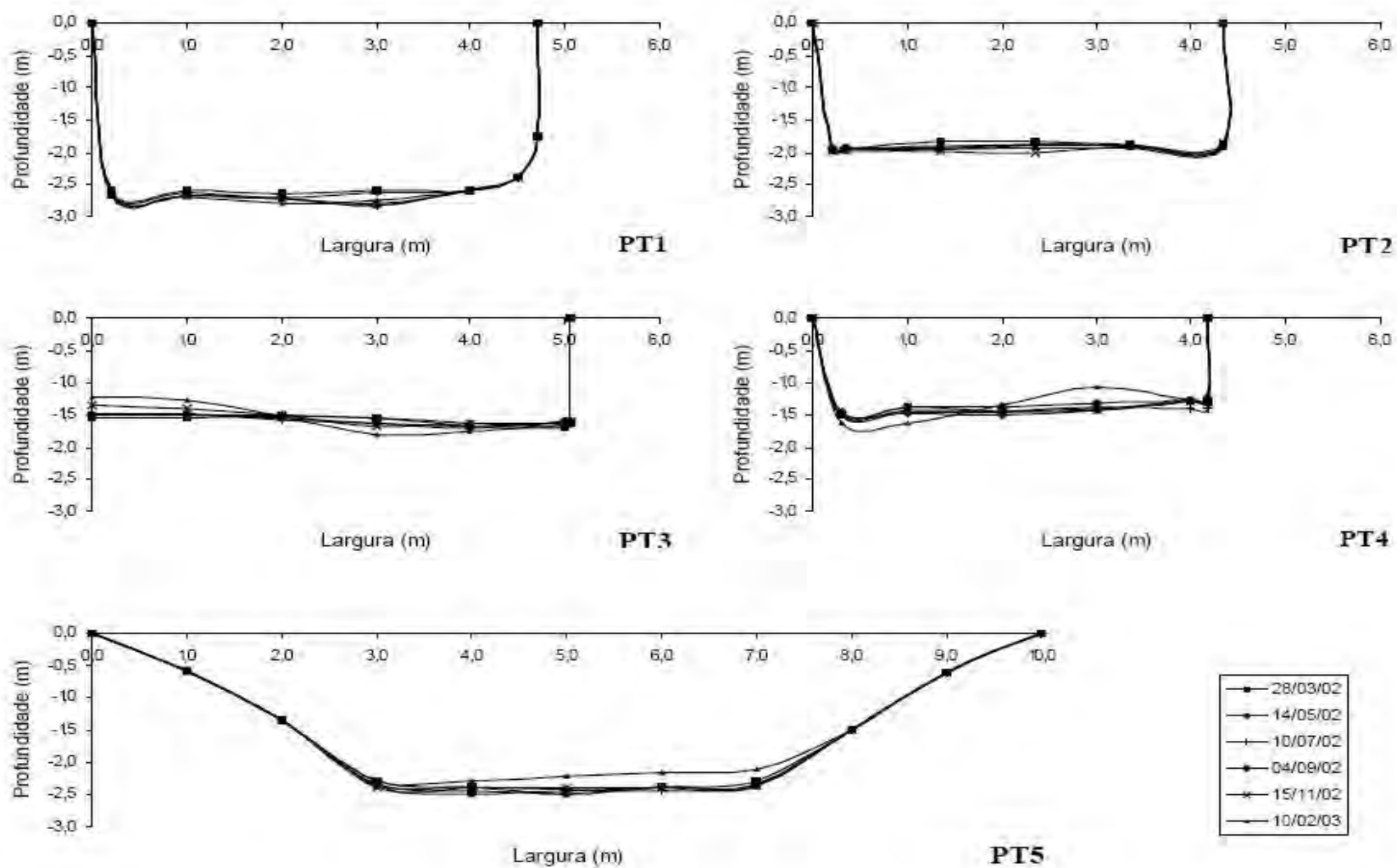

Figura 5 - Sucessivos perfis transversais do canal do rio dos Macacos entre março/2002 e fevereiro/2003.

Setor B - (PT2, PT3 e PT4)

No PT2 as principais mudanças concentraram-se no ligeiro aumento da profundidade do talvegue $(0,03 \mathrm{~m})$ e da profundidade média $(0,05 \mathrm{~m})$ que refletiram no aumento da área da seção transversal em $0,21 \mathrm{~m}^{2}$, passando de 8,27 para $8,48 \mathrm{~m}^{2}$ (Tabela 2). Desta forma, o índice da forma do canal, obtido através da relação $L / P$, variou de 2,29 a $2,23 \mathrm{~m}$, mostrando um aumento da profundidade em relação a largura que caracteriza o processo de erosão do leito e a forma do canal como profundo e estreito (Figura 5).
O PT3 foi o que apresentou maiores mudanças quanto a geometria, devido a sinuosidade do talvegue. As maiores velocidades de fluxo concentram-se na margem côncava, enquanto que ocorre a deposição de sedimentos grosseiros na margem convexa, originando as soleiras. Desta forma, a deposição de sedimentos favorece a fixação da vegetação no banco de sedimentação, que serve como obstáculos para a passagem do fluxo.

A área da seção transversal, neste ponto, apresentou redução de $0,30 \mathrm{~m}^{2}$, passando de $8,08 \mathrm{~m}^{2}$ para $7,78 \mathrm{~m}^{2}$, evidenciando o processo de assoreamento do leito. O ligeiro 
aumento da calha verificado no último trabalho de campo (10/02/03), para $7,83 \mathrm{~m}^{2}$, está relacionado ao aumento do fluxo e do processo de entalhamento do talvegue, pela concentração de $360 \mathrm{~mm}$ de chuva ocorrida no mês de janeiro (Tabela 2, Figura 5).

O raio hidráulico, que vinha mantendose entre os valores de 0,09 e 0,20m, também apresentou uma elevação no último trabalho de campo, passando para $0,27 \mathrm{~m}$, fato que evidencia aumento na eficiência do canal, pela eliminação das rugosidades do fundo.

Através do aumento gradativo dos valores da relação largura / profundidade (L/ P), de 3,16 para 3,28m, observou-se a tendência da forma do canal como raso e largo, devido ao assoreamento.

No ponto PT4, houve um aumento gradativo na profundidade do talvegue de 1,45 para $1,63 \mathrm{~m}$, enquanto que a área da seção transversal apresentou valores irregulares

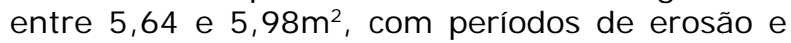
assoreamento (Tabela 2, Figura 5). A maior variação na morfologia de fundo aconteceu no último trabalho de campo (10/02/03) estando relacionada à precipitação de $360 \mathrm{~mm}$ registrada no mês de janeiro.

Os valores de vazão variaram de forma irregular entre 0,13 a $0,50 \mathrm{~m}^{3} / \mathrm{s}$ em consequência não só da precipitação, como também de outros fatores importantes. Neste ponto, além de ocorrer o desvio de parte da água do rio dos Macacos para o canal do Jóquei, que funciona com um sistema de comporta operado pelos funcionários do Jardim Botânico, também observou-se a presença de uma caixa de contenção de sedimentos e de tubulações de esgoto no leito do canal, à jusante do ponto, contribuindo para o assoreamento e a redução da velocidade do fluxo.

O raio hidráulico apresentou valores irregulares, indicando uma tendência a baixa eficiência de escoamento do fluxo entre 0,19 e $0,29 \mathrm{~m}$.

\section{Setor C - (PT5)}

No PT5 a largura manteve-se constante (10m) por se tratar de um trecho concretado, enquanto a profundidade do talvegue apresentou uma redução de $0,20 \mathrm{~m}$ comprovando o assoreamento do leito (Tabela 2).

No último trabalho de campo (10/02/03), houve uma redução no valor da profundidade média $(0,09 \mathrm{~m})$, em relação ao aumento da pluviosidade registrada no mês de janeiro (360mm), acarretando a redução de $0,90 \mathrm{~m}^{2}$ na área da seção transversal (Figura 5).

Com isso, as modificações observadas na área da seção transversal para esse ponto, ao longo do período estudado, indicam processos de erosão e deposição que estão relacionados às variações do fluxo, provenientes das precipitações e do aumento do escoamento pluvial das áreas impermeabilizadas pela atividade humana, e das correntes de retorno do corpo receptor (Lagoa Rodrigo de Freitas), impedindo que a água chegue ao seu destino final.

Os valores obtidos da relação largura e profundidade entre 5,59 e $5,95 \mathrm{~m}$ indicam a forma do canal neste trecho como raso e largo, predominando o processo de assoreamento do leito.

\section{Perfil Longitudinal}

Apesar das maiores precipitações diárias terem sido registradas no mês de novembro de 2002, as modificações mais expressivas foram registradas no mês de janeiro de 2003 para todos os pontos, onde a precipitação ocorreu de forma distribuída, em 19 dias do mês.

A largura (L) manteve-se constante ao longo do período estudado por se tratar de seções com pontes e margens concretadas ou compostas por blocos encaixados, com afunilamento em direção à montante.

$$
\text { A redução da área das seções }
$$


Rede de drenagem urbana em área tropical: mudanças na morfologia do canal

e níveis de poluição das águas - Rio dos Macacos - Rio de Janeiro - RJ, pp. 39 - 64

transversais pode ser observada nos pontos PT3 $\left(0,30 \mathrm{~m}^{2}\right)$, PT4 $\left(0,08 \mathrm{~m}^{2}\right)$ e PT5 $\left(0,90 \mathrm{~m}^{2}\right)$ que estão mais próximos à jusante, comprovando o processo de deposição e assoreamento do leito, enquanto que, o aumento ocorreu nos pontos PT1 $\left(0,28 \mathrm{~m}^{2}\right)$ e PT2 $\left(0,021 \mathrm{~m}^{2}\right)$, evidenciando os processos de erosão e entalhamento do talvegue à montante. Desta forma, o canal caracterizou-se como largo e raso nos pontos PT3, PT4 e PT5 e estreito e profundo nos pontos PT1 e PT2.

O ponto PT4, por sua vez, caracterizouse por ser o ponto mais crítico, onde as mudanças no canal estão relacionadas não só com a precipitação, mas também com a maior interferência antrópica.

\section{III.III- Impactos Antrópicos na qualidade das águas}

Nos últimos anos algumas fontes de poluição de recursos hídricos como esgotos sanitários, águas residuárias industriais, resíduos sólidos (lixo), águas de drenagem urbana, fontes acidentais e fontes atmosféricas passaram a assumir importância significativa. Estes fatores, provenientes do processo de crescimento e desenvolvimento urbano desordenado, são os responsáveis pelos valores elevados nos níveis de poluição dos rios brasileiros.

A ação do homem sobre os recursos hídricos é o principal responsável pelas alterações na composição da água. Por muitos anos, os rios têm sido depositários de rejeitos que alteram profundamente seu estado natural. Os esgotos urbanos que lançam efluentes orgânicos, as indústrias que despejam uma série de compostos químicos e metais pesados, e a agricultura que é responsável pela presença de pesticidas e excesso de fertilizantes na água estão diretamente relacionados com algumas das alterações sofridas na qualidade da água, o que reoresenta uma das maiores evidências do impacto das atividades humanas sobre a biosfera (PORTO et al., 1991).
Por um bom tempo, apenas os sentidos da visão, sabor e olfato eram os parâmetros utilizados na avaliação da qualidade da água. Com a evolução de técnicas de detecção e medidas de poluentes, foram estabelecidos padrões de qualidade para a água, isto é, a quantidade máxima de concentração de elementos ou compostos que poderiam estar presentes na água, de modo que fosse compatível com a sua utilização para determinados fins. Desta forma, estabeleceu-se padrões de qualidade da água para usos como abastecimento público e industrial, preservação da vida aquática, irrigação, recreação, agricultura, navegação e paisagismo. Esses padrões surgiram a partir de experimentos realizados em centros de pesquisa de países desenvolvidos (BENETTI e BIDONE, 1997).

No Brasil, a classificação das águas foi definida pela Resolução № 20, de 18 junho de 1986, instituída pelo Conselho Nacional do Meio Ambiente (CONAMA). Esta resolução estabeleceu 9 classes, sendo 5 de água doce, 2 de águas salobras e 2 de águas salinas, de acordo com o grau de salinidade. Neste caso, as águas doces foram divididas em classes, definindo-se para cada uma, os usos a que se destinavam e os requisitos a serem observados.

Para a caracterização da poluição das águas do rio dos Macacos foram instaladas cinco estações (pontos) de monitoramento, de forma que abrangessem os três setores do canal. Realizou-se cinco coletas mensais, por um período de cinco meses, definidas pela Fundação Estadual de Engenharia do Meio Ambiente (FEEMA), responsável, também, pela análise das amostras em laboratório.

Foram considerados os seguintes parâmetros: físicos (temperatura), químicos $(\mathrm{pH}$, oxigênio dissolvido e demanda bioquímica de oxigênio) e biológicos (coliformes fecais e totais), e os dados obtidos nas estações de coleta foram analisados e classificados de acordo com os padrões indicados pelo CONAMA (Resolução № 20, 1986), para águas da classe 2. 


\section{Temperatura}

A temperatura da água, obtida em campo através de termômetro, oscilou entre 25,5 으 em 20/05/02 e 21 으 em 22/07/02. No dia em que foi registrado o valor mais baixo de temperatura $(21 \mathrm{C})$ observou-se a ocorrência dos valores mais elevados de ph e os menores de oxigênio dissolvido (Tabela 3).

A temperatura é um fator que pode afetar a fauna e a flora aquáticas, quando ocorre o lançamento de efluentes industriais com temperaturas elevadas provocando a poluição térmica dos rios. Além disso, a elevação da temperatura da água provoca a redução do oxigênio dissolvido, agravando ainda mais os problemas de poluição (AMARAL, 2002).

\section{pH}

Representa a atividade hidrogeniônica, ou seja, a intensidade dos ácidos e álcalis presentes em uma solução, indicando o caráter ácido ou alcalino da água. Seus valores variam entre 0 e 14, classificando-se como: ácidos ( $\mathrm{pH}$ $>7)$, neutros $(\mathrm{pH}=7)$ e alcalinos $(\mathrm{pH}<7)$. Valores baixos de $\mathrm{pH}$ tornam a água corrosiva enquanto que valores elevados tendem a formar incrustações nas tubulações (MOTA, 1997).

Alterações no $\mathrm{pH}$ da água podem prejudicar a fauna e flora aquáticas, devendo ser mantido entre os valores 6 e $9 . \mathrm{O}$ pH neutro não indica, necessariamente, que a água seja pura mas que ela apresenta equilíbrio entre as substâncias ácidas e alcalinas (BENETTI e BIDONE, 1997).

$\mathrm{O} \mathrm{pH}$ foi determinado através do método colorimétrico, supondo que soluções diferentes tenham a mesma concentração de íons de hidrogênio, se produzirem intensidade de cores iguais (CLESCERI et al., 1998). Sendo assim, o método colorimétrico baseia-se nas alterações sofridas em certos corantes, de acordo com as mudanças do $\mathrm{pH}$.

De modo geral, os valores de $\mathrm{pH}$ concentraram-se entre 6,1U.pH (PT3) em 20/05/ 02 e 7,0 U.pH (PT5) em 22/07/02 para todas as amostras, estando dentro das normas estipuladas pelo CONAMA $(6,0$ a $9,0 \mathrm{U} . \mathrm{pH})$. Os valores mais baixos de $\mathrm{pH}$ foram observados no dia 20/05/02 entre 6,1 e 6,3 U.pH. Os valores mais elevados, entre 6,7 e 7,0 U.pH, registraram-se no dia 22/07/02 (Tabela 3, Figura $6)$.

Os resultados obtidos indicam águas propícias para o desenvolvimento da fauna e da flora aquáticas e não corrosivas quanto às condições de formar incrustações em tubulações.

Figura 6 - Distribuição dos valores de pH

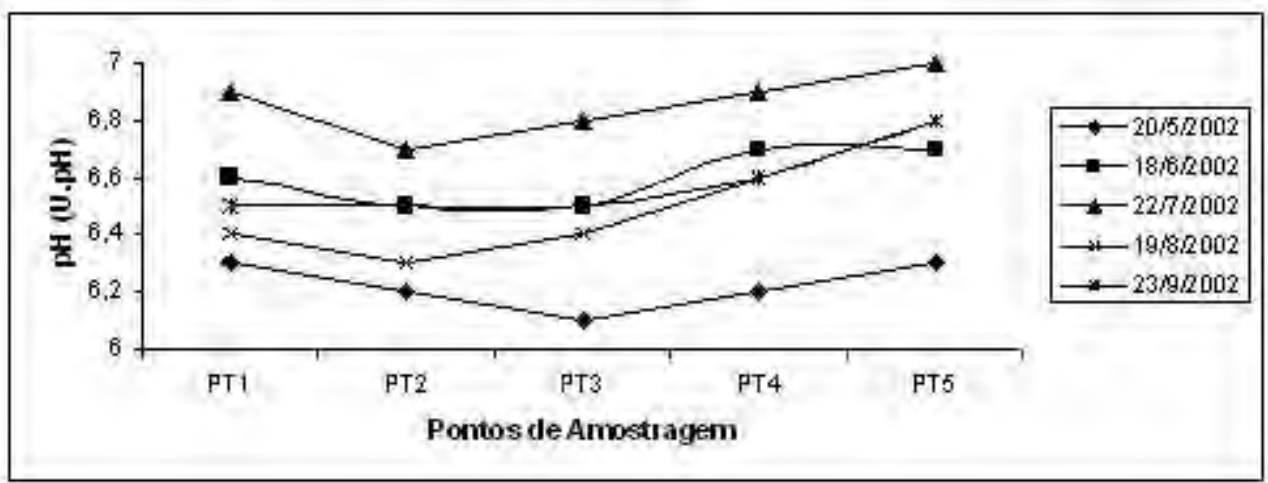


Rede de drenagem urbana em área tropical: mudanças na morfologia do canal

e níveis de poluição das águas - Rio dos Macacos - Rio de Janeiro - RJ, pp. 39 - 64

Tabela 3 - Dados de poluição das águas do rio dos Macacos - ano 2002

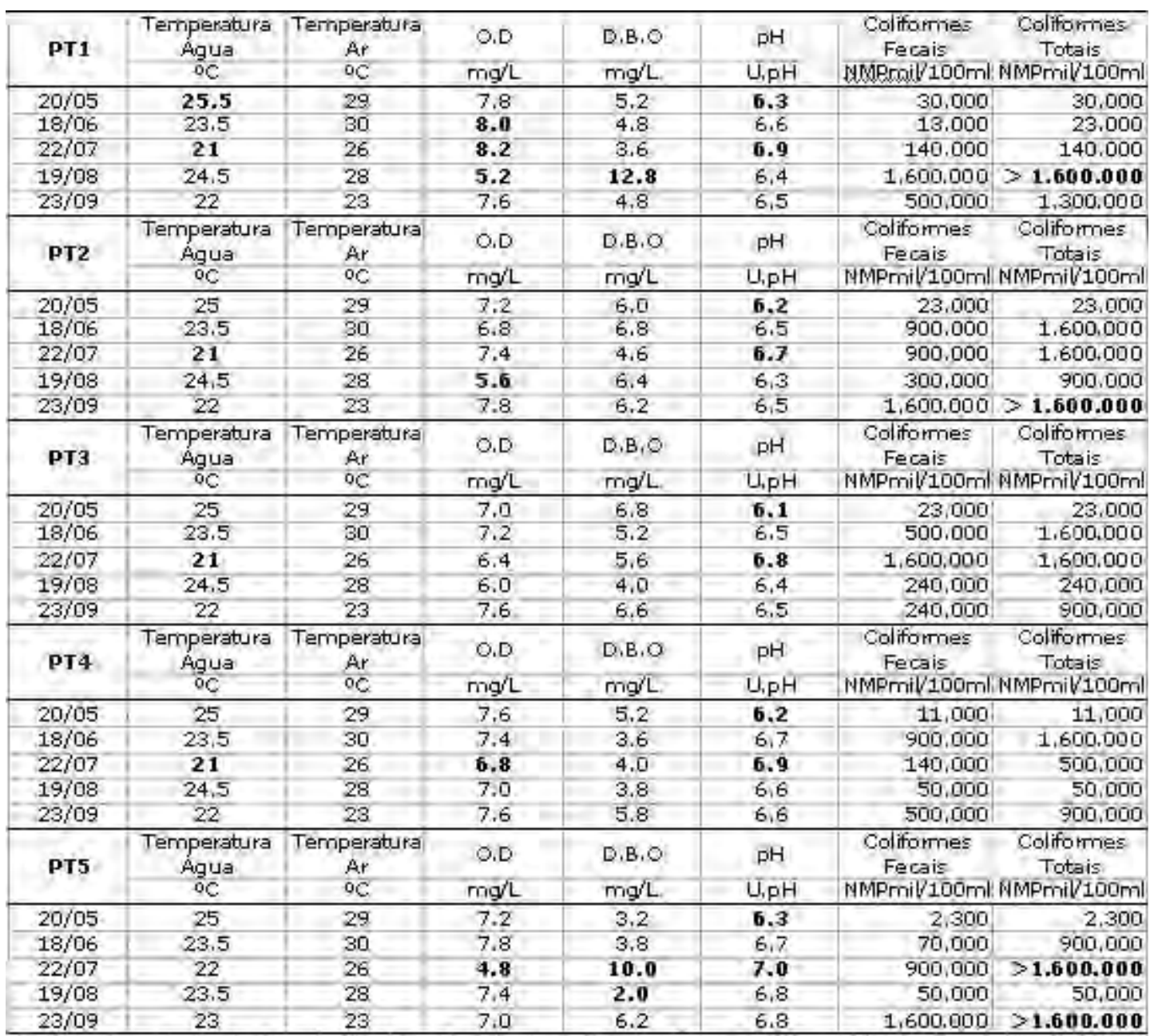

Fonter Secretaria de Estado de Meio Ambiente e Desenvolvimento Sustetável - Fundaça Estaduall de Engenharia do Meio Ambiente (FEEMA)

\section{Oxigênio Dissolvido (OD)}

O oxigênio dissolvido provém da dissolução do oxigênio atmosférico e da fotossíntese de microorganismos vivos na água. Sua solubilidade está associada a altitude, temperatura e salinidade do corpo d'água (MURARO, 2001). Ele é um dos principais parâmetros de caracterização dos efeitos da poluição das águas decorrentes dos despejos orgânicos, já que para o processo de decomposição são consumidos altos índices de oxigênio.

Com a redução do OD na água, algumas espécies de peixes não sobrevivem e acabam morrendo por asfixia. Além disso, caso a taxa de OD caia para zero, as águas dos rios passam a exalar maus odores, prejudicando o bem estar 
7 - Distribuição dos valores de oxigênio dissolvido (OD)

das populações que habitam próximo ao rio (AMARAL, 2002).

No que se refere a quantidade de oxigênio dissolvido (OD) pode-se dizer que a água apresenta boa qualidade quando as águas superficiais estão saturadas de oxigênio (BRANCO e ROCHA, 1977). Neste caso, a água poderá ou não estar poluída, mas a saturação indicará que não está contaminada por matéria oxidável. A taxa recomendada para concentração de OD na água deve situar-se entre 8 a $11 \mathrm{mg} / \mathrm{l}$, onde valores iguais ou inferiores a 5,0 mg/l são prejudiciais à vida aquática e passam a comprometer o ecossistema fluvial (CONAMA, 1986).

Para a determinação do oxigênio dissolvido utilizou-se o método de Winkler, a partir de REBELLO e CARREIRA (1997), adaptado de GRASSHOFF et al. (1983), que consiste na análise da amostra em etapas.

O oxigênio dissolvido (OD) apresentou valores entre $8,2 \mathrm{mg} / \mathrm{L}$ (PT1) e $4,8 \mathrm{mg} / \mathrm{L}$ (PT5) registrados no dia 22/07/02, com ligeira redução em direção à jusante (Tabela 3). No PT1 foram obtidos os maiores valores para $\operatorname{OD}(8,0$ e $8,2 \mathrm{mg} / \mathrm{L}$ ) em 18/06/02 e 22/07/02, evidenciando a maior disponibilidade de oxigênio, neste ponto, para as reações químicas e biológicas. 0 valor mais baixo foi registrado no PT5 $(4,8 \mathrm{mg} /$ L) em 22/07/02, estando associado à maior concentração de efluentes e à baixa energia do fluxo neste ponto (Figura 7).

Figura 7 - Distribuição dos valores de oxigênio dissolvido (OD)

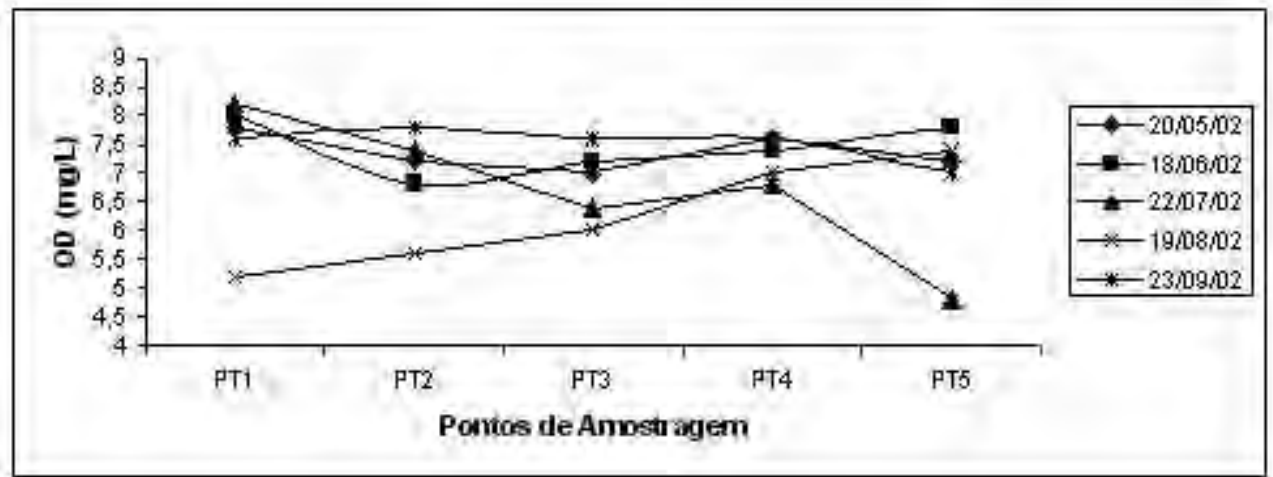

\section{Demanda Bioquímica De Oxigênio (DBO)}

Este parâmetro avalia a quantidade de matéria orgânica biodegradável presente na amostra, indicando o consumo de oxigênio a partir da atividade de algas e/ou bactérias, ou seja, indica a quantidade de oxigênio que a matéria poluidora biodegradável necessita para retirar da água em seu processo de biodegradação (BENETTI e BIDONE, 1997).

Para BRANCO e ROCHA (1977) a demanda bioquímica de oxigênio (DBO) é a quantidade de oxigênio necessária para a total estabilização de determinada quantidade de matéria orgânica sujeita à decomposição. Segundo o autor, as fontes de fornecimento de oxigênio para a água são o próprio ar atmosférico em contato com a água, através da turbulência desta, e a atividade fotossintetizante das algas microscópicas.

As taxas adequadas para a demanda bioquímica de oxigênio devem concentrar-se entre $3 \mathrm{mg} / \mathrm{l} \mathrm{O} \mathrm{O}_{2}$ e $5,0 \mathrm{mg} / \mathrm{I} \mathrm{O}_{2}$ (CONAMA, 1986). Valores acima desta quantidade indicam a poluição da água dos rios com efluentes domésticos e industriais. 
Rede de drenagem urbana em área tropical: mudanças na morfologia do canal

e níveis de poluição das águas - Rio dos Macacos - Rio de Janeiro - RJ, pp. 39 - 64

O método utilizado para determinação da DBO foi o de diluição, baseado no princípio de que a velocidade de degradação da matéria orgânica é diretamente proporcional à quantidade de matéria orgânica remanescente. Assim, a utilização do oxigênio, em uma amostra diluída a $10 \%$, é feita a uma velocidade que será dez vezes menor do que a da amostra não diluída (CLESCERI et al., 1998).

Os valores de demanda bioquímica de oxigênio (DBO) variaram entre $12,8 \mathrm{mg} / \mathrm{L}$ (PT1) em 19/08/02 e 2,0 mg/L (PT5) em 19/08/02 (Tabela 3 ). Todos os pontos apresentaram índices elevados de DBO, quando comparados com a classificação do CONAMA, caracterizando o aumento do consumo de oxigênio pela matéria orgânica biodegradável, ao longo do canal. Ocorrências anômalas foram registradas no ponto PT1 $(12,8 \mathrm{mg} / \mathrm{L})$ em $19 / 08 / 02$ e no ponto PT5 em 22/07/02 (Figura 8).

De acordo com a média, as maiores concentrações de DBO foram encontradas nos pontos PT1 e PT2 (6,2 e $6,0 \mathrm{mg} / \mathrm{L})$ sendo possível observar a tendência de diminuição destes valores em direção à jusante.

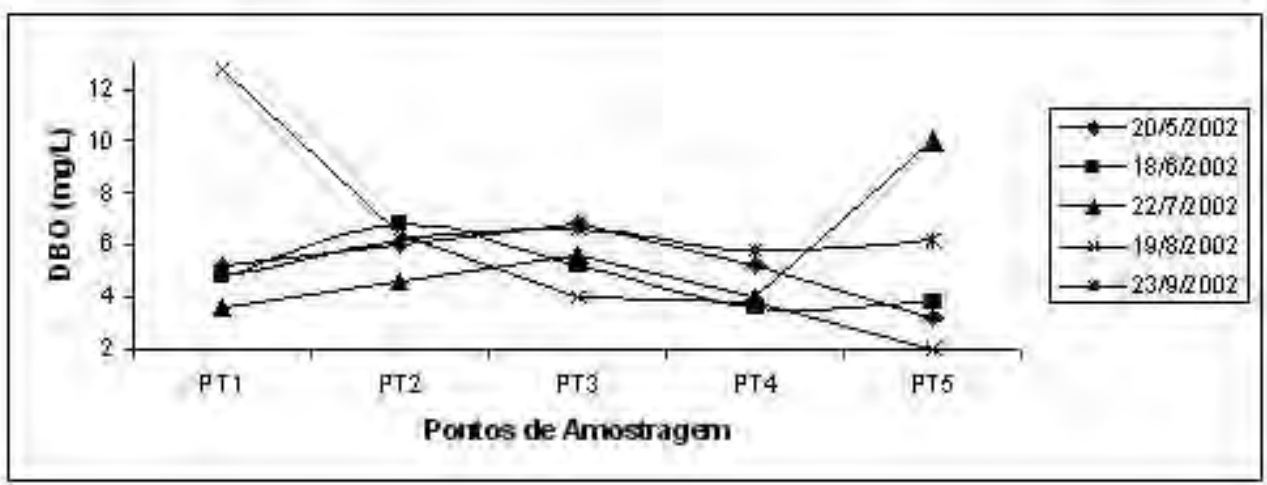

Figura 8 - Distribuição dos valores de demanda bioquímica de oxigênio (DBD)

\section{Colimetria (Coliformes Fecais e Totais)}

Os coliformes são bactérias que vivem normalmente em grande número no intestino humano e de animais de sangue quente. Sua presença num curso d'água pode estar relacionada com o lançamento de esgotos domésticos e fezes de animais. Um grande número de microorganismos patogênicos pode estar presentes nos esgotos, sendo necessário o teste de coliformes como indicador geral da qualidade bacteriológica da água, e sua presença a torna suspeita para o consumo (AMARAL, 2002).

O teste de coliformes fecais consiste na análise de presença de bactérias e organismos na água, originados da matéria fecal produzida pelo ser humano, sendo permitido até 1.000 coliformes para cada $100 \mathrm{ml}$ de amostra (BENETTI e BIDONE, 1997). As bactérias coliformes tendem a morrer mais ou menos rapidamente em contato com o meio externo, cujos agentes destruidores são: a luz, o oxigênio, microorganismos predadores e a sedimentação por gravidade.

A análise foi realizada através do método de diluição que consiste no princípio da contagem da densidade bacteriana pelo Número Mais Provável (NMP), adaptado por Parnow, em 1972 (apud MURARO, 2001).

Os coliformes fecais apresentaram 
valores elevados que oscilaram de forma irregular, ao longo do período, entre 2.300 Número Mais Provável/100 ml (PT5 em 20/05/ 02) e $>1.600 .00 \mathrm{NMP} / 100 \mathrm{ml}$ (PT1 em 19/08/02, PT2 em 23/09/02 e PT5 em 22/07/02) (Tabela
3, Figura 9). Da mesma forma, os coliformes totais também apresentaram valores elevados situando-se entre $2.300 \mathrm{NMP} / 100 \mathrm{ml}$ (PT5) e > $1.600 .000 \mathrm{NMP} / 100 \mathrm{ml}$ (PT1, PT2 e PT5), nas mesmas datas anteriormente citadas (Tabela 3, Figura 10).

Figura 9 - Distribuição dos valores de coliformes fecais

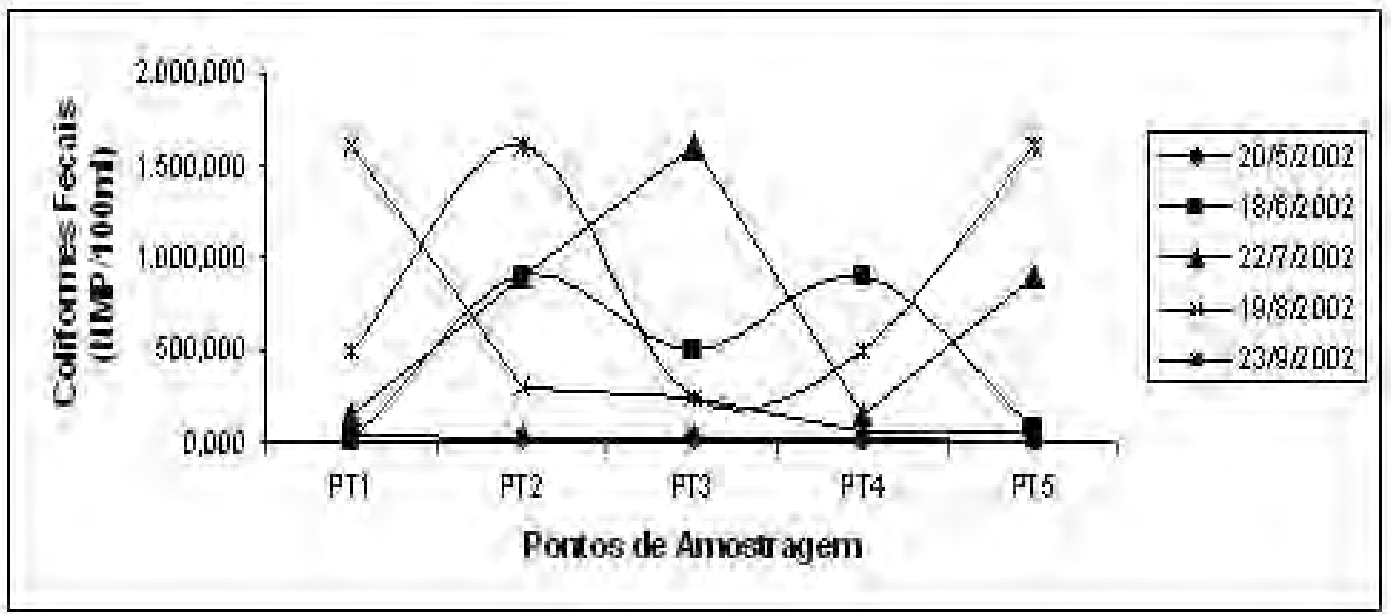

Figura 10 - Distribuição dos valores de coliformes totais

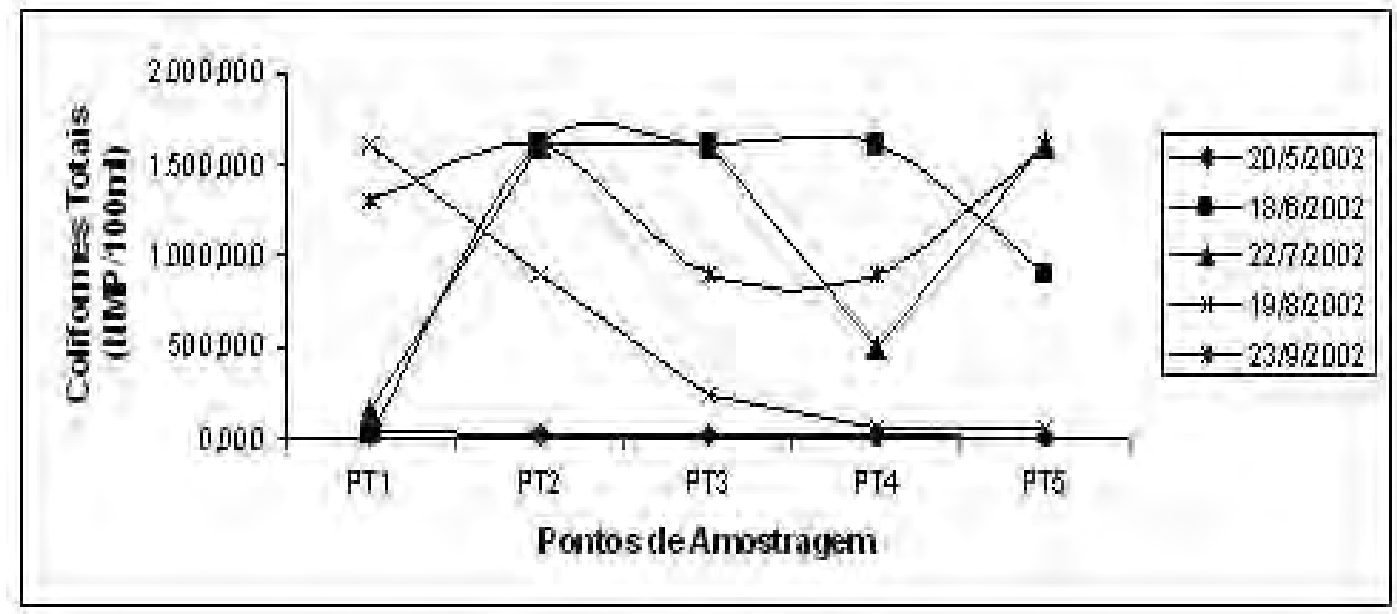


Rede de drenagem urbana em área tropical: mudanças na morfologia do canal

De acordo com a resolução do CONAMA (Resolução № 20, 1986), as águas do canal do rio dos Macacos apresentaram índices elevados de coliformes fecais e totais acima dos limites estipulados para águas da Classe 2, sendo estabelecido para coliformes totais até 5.000 NMP/100 ml. Neste caso, os altos índices de coliformes fecais indicam contaminação da água por fezes, favorecendo a transmissão de doenças e a presença de odores desagradáveis, porém ainda com ocorrência de vida aquática.

\section{Rede de Esgoto e Escoamento Pluvial}

A rede de esgoto é administrada pela Companhia Estadual de Águas e Esgotos (CEDAE) e funciona neste ponto com uma rede de tubulações simples, principal, recalques (bombeadores) e elevatória, ligadas ao sistema interceptor oceânico, realizando a disposição dos esgotos sanitários em um ponto situado a $27 \mathrm{~m}$ de profundidade e a cerca de $4 \mathrm{~km}$ da costa.

Porém, com o aumento da urbanização, é comum observar o lançamento de esgotos sanitários na rede de água pluvial através de ligações clandestinas ou até mesmo o lançamento direto no rio como foi evidenciado no setor $A$, onde encontram-se casas nas margens do canal. No setor $B$, próximo ao PT4, dentro do Jardim Botânico, foram encontrados dois locais de lançamento de esgoto, provenientes de edifícios vizinhos ao parque, que interferem diretamente na qualidade da água e na morfologia de fundo através da inserção de tubulações no leito do canal. (Figura 11 el2).

Figura 11 - Lançamento de efluentes domésticos à montante do ponto PT4, evidenciando as modificações na qualidade da água e na morfologia de fundo devido à interferência antrópica (Foto: setembro de 2002, Crédito: L. Lucas).

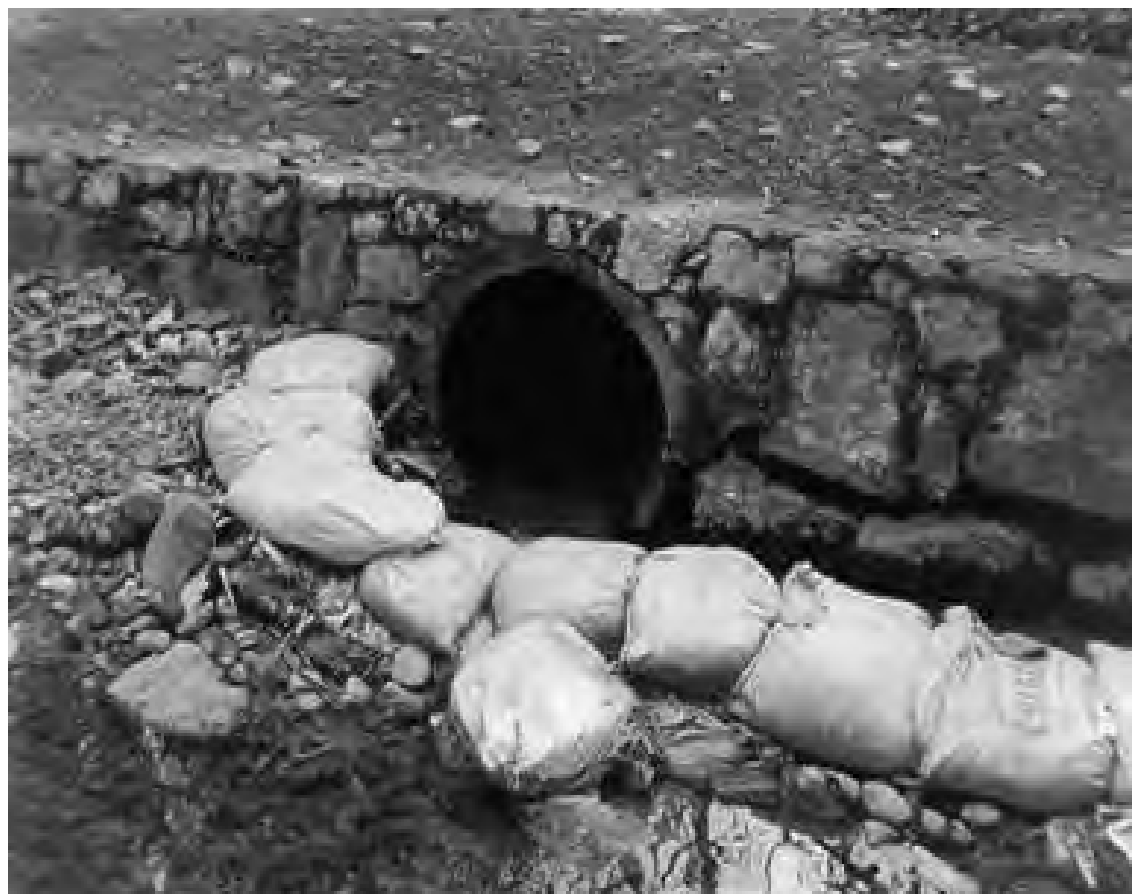




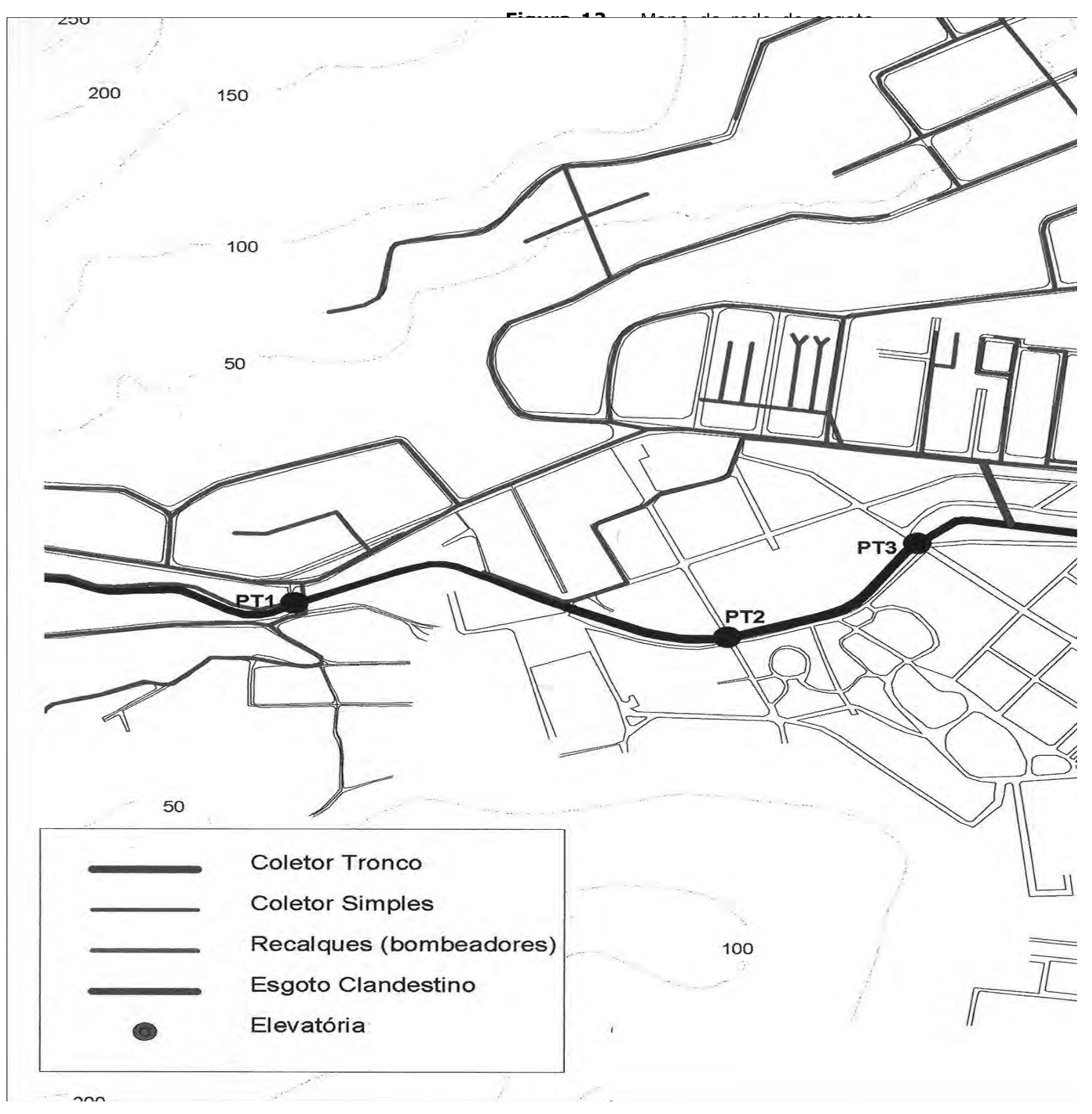


Rede de drenagem urbana em área tropical: mudanças na morfologia do canal

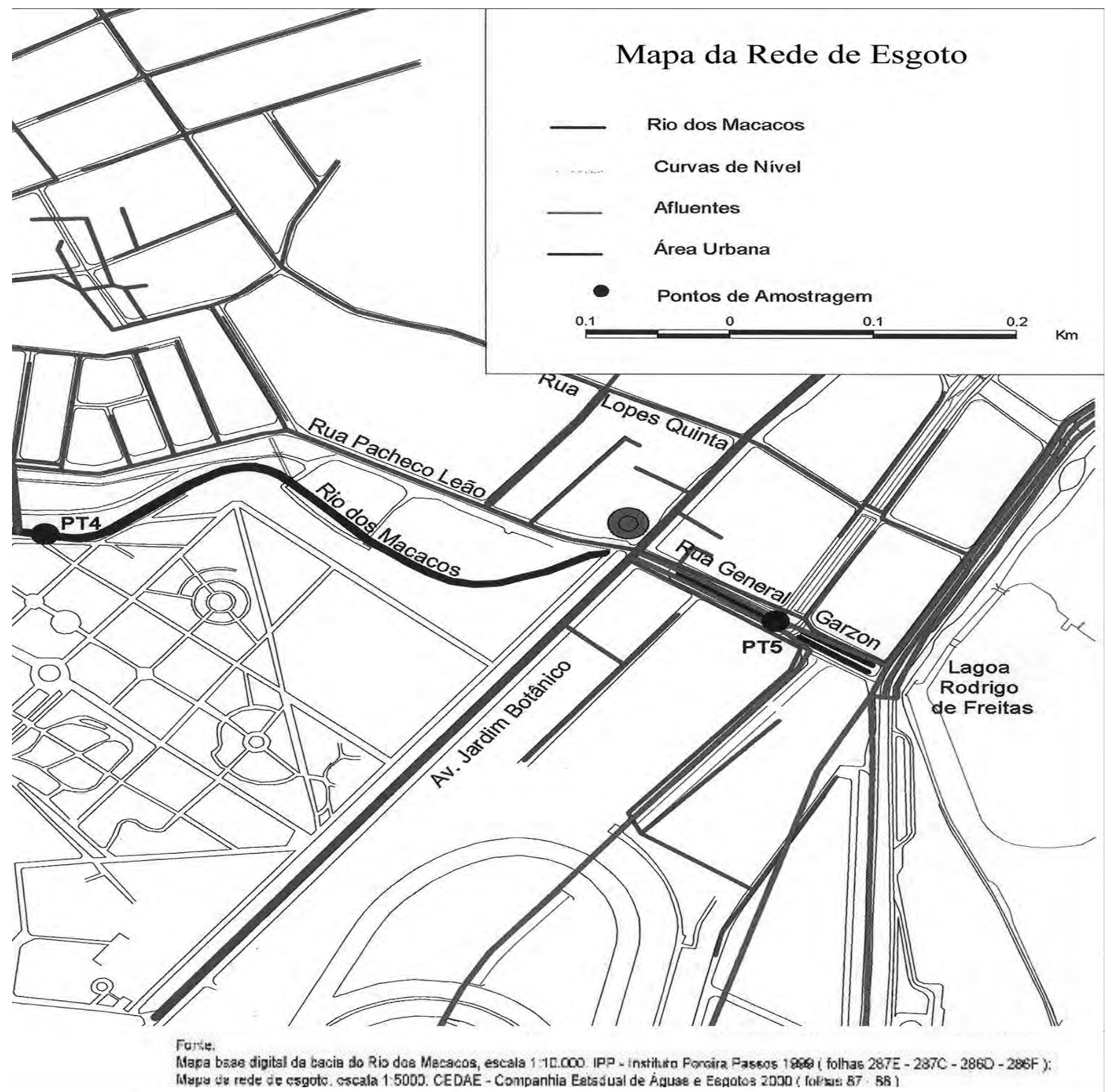


A rede de escoamento pluvial compreende tais ruas principais: Rua Pacheco Leão, Av. Jardim Botânico e Rua General Garzon. $\mathrm{Na}$ rua Pacheco Leão há três locais de lançamento do escoamento pluvial dentro do canal: dois próximos à seção transversal do ponto PT4 (Figura 13 e 14) e outro no cruzamento com a Av. Jardim Botânico. O escoamento da Av. Jardim Botânico, por sua vez, compreende o trecho entre a rua transversal Lopes Quinta (margem esquerda do canal) e um pequeno trecho em frente ao Jardim Botânico (margem direita do canal). A rua General Garzon não possui um sistema complexo de escoamento, apenas valas no meio fio que escoam direto para dentro do canal.

A rede de águas pluviais apresenta-se normalmente obstruída pelo lixo lançado pela população e por detritos provenientes das encostas que, associados à impermeabilização do solo devido ao asfalto, contribuem para uma resposta imediata na vazão do canal, em períodos de chuva, através das inundações.

Figura 13 - Vala localizada dentro do Jardim Botânico, à montante do ponto PT4, que canaliza parte do escoamento pluvial da Rua Pacheco Leão para dentro do canal (Foto: setembro de 2002, Crédito: L. Lucas).

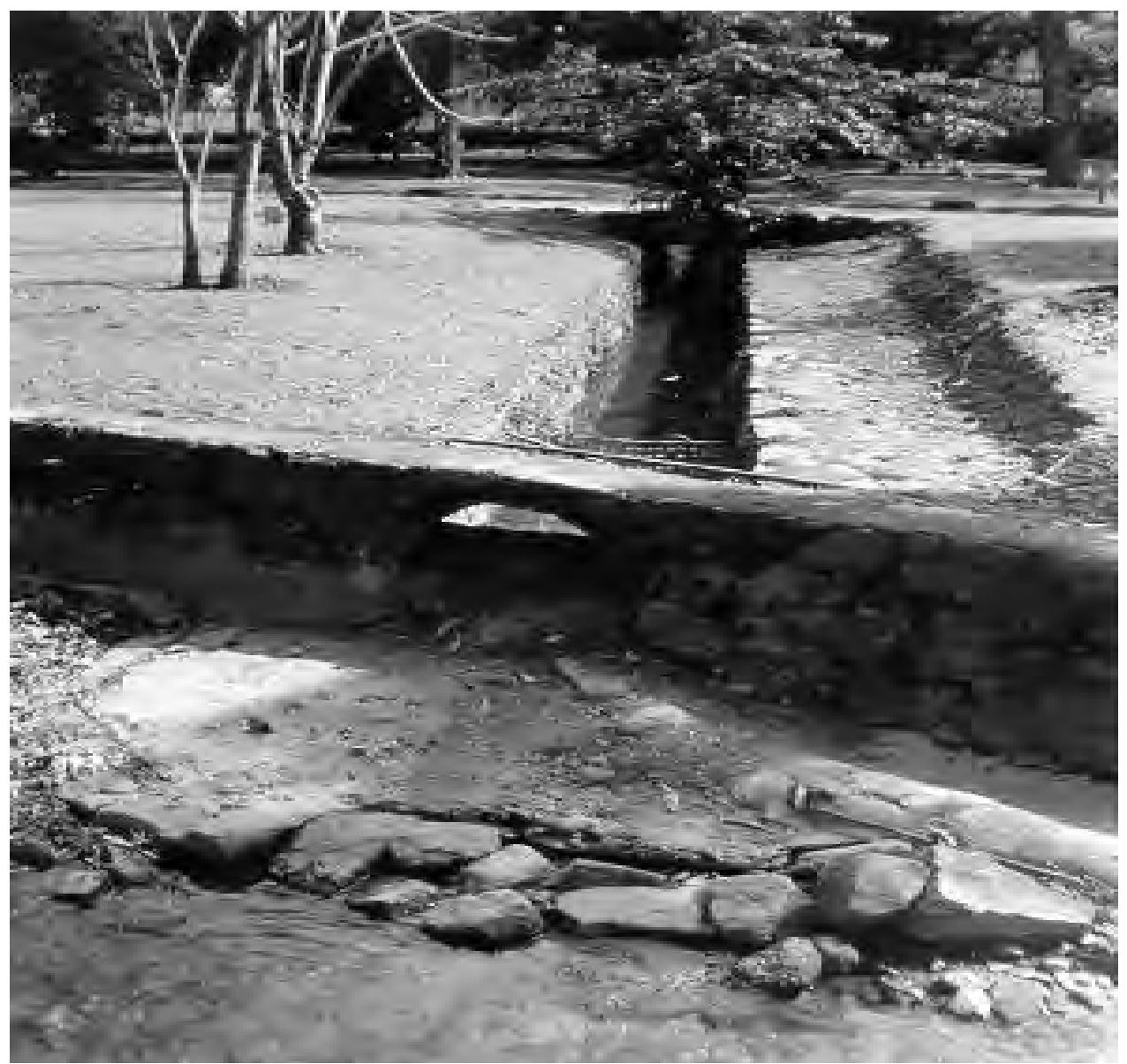


Rede de drenagem urbana em área tropical: mudanças na morfologia do canal

Figura 14- Mapa da rede de escoamento pluvial

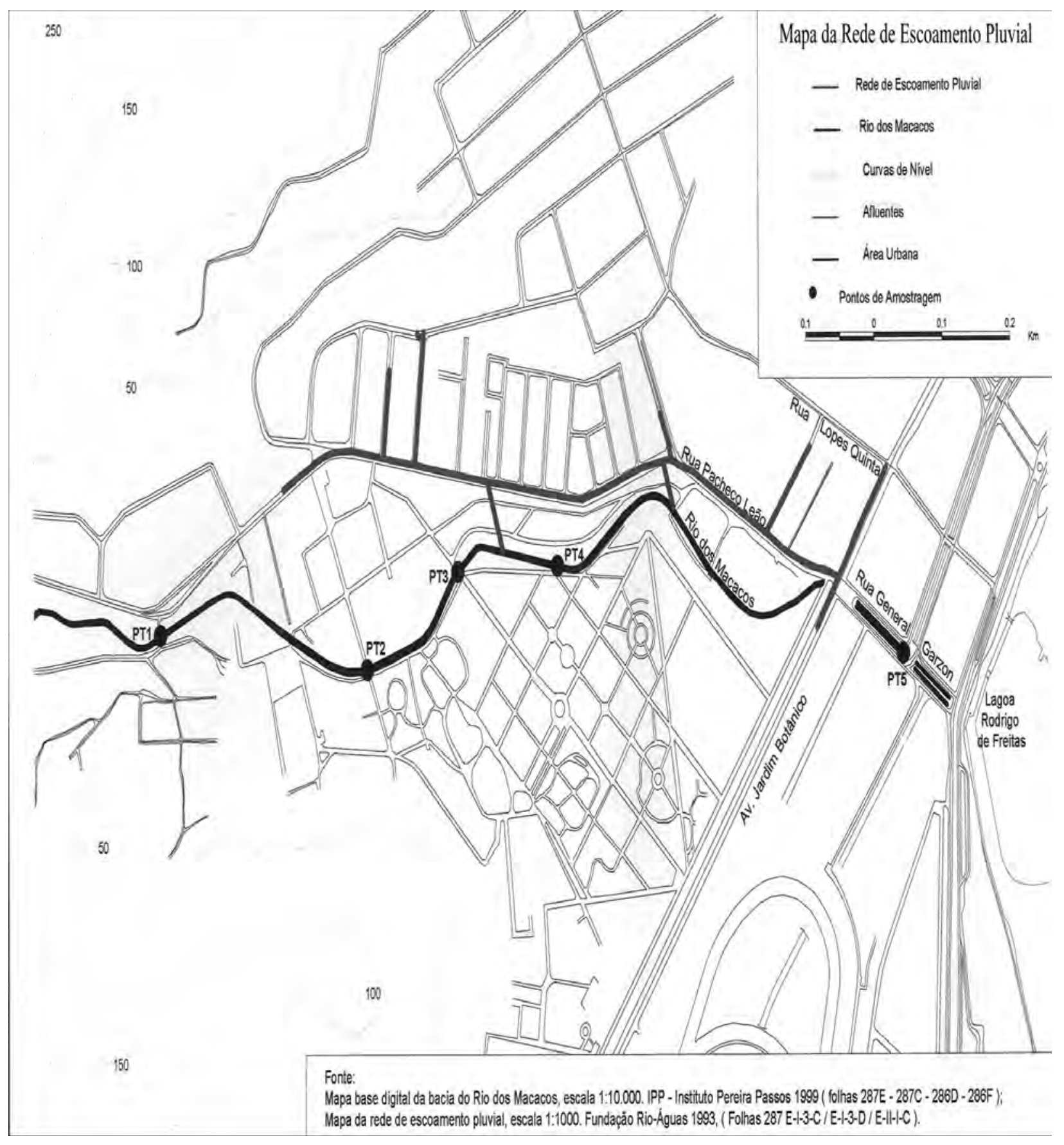




\section{IV- Considerações Finais}

Ao longo do período estudado, foi possível perceber que o canal do rio dos Macacos vem sofrendo modificações em sua geometria, através, primeiramente, das obras de engenharia, refletindo no comportamento dos sedimentos, pelo assoreamento do leito. Além disso, as intensas modificações ao longo do tempo, relacionadas à ocupação das áreas marginais, têm afetado as características naturais do rio sobretudo a vida aquática, fazendo com que ela busque novas condições de equilíbrio no meio em que estão inseridas.

Nos pontos analisados observou-se que a largura do canal manteve-se constante devido à estabilidade das margens, compostas por concreto e blocos encaixados que dificultam o processo erosivo proveniente do fluxo e do escoamento superficial. Sendo assim, os valores de largura mantiveram-se em $4,70 \mathrm{~m}$ no setor $A$ (PT1) a montante, enquanto que para o setor $C$ (PT5) a jusante, o valor manteve-se em 10m. Valores inferiores a $4,70 \mathrm{~m}$ foram encontrados no setor B (PT2 e PT4) com 4,35 e 4,18m, respectivamente, o que comprova o estrangulamento ao longo do canal.

Através dos valores obtidos da relação L/P, constatou-se a intensificação dos processos de erosão e entalhamento do talvegue para os pontos mais próximos à montante, com redução de $0,04 \mathrm{~m}$ (PT1) e 0,06m (PT2). Ao contrário disso, o aumento nos valores de L/P foram registrados nos pontos mais à jusante de $0,10 \mathrm{~m}$ (PT3) e 0,30 (PT5) que caracterizam os processos de deposição e assoreamento do leito.

Períodos de erosão e deposição foram identificados no setor B (PT4) estando relacionados com a precipitação e com outros fatores como o desvio de parte da água do canal, a construção de uma caixa de contenção de sedimentos e a presença de tubulações de esgoto no leito, que contribuem para o assoreamento e a redução da eficiência de escoamento do fluxo.
Fatores naturais, agravados pela atuação antrópica, promoveram alterações na morfologia do canal, onde observou-se reduções de até $0,90 \mathrm{~m}^{2}$ na capacidade do canal nos setores $B$ e $C$, enquanto que o aumento da capacidade do canal concentrou-se principalmente no setor A com valores de até $0,28 \mathrm{~m}^{2}$. Com isso, verifica-se a tendência na redução da capacidade do canal de montante para jusante.

Quanto aos níveis de poluição das águas do canal, identificou-se que o nível de $\mathrm{pH}$ da água, embora esteja entre os índices estabelecidos pelo CONAMA (Resolução № 20, 1986), apresentou uma tendência para a acidez devido a lixiviação do solo pela água da chuva, seja pelo material transportado pelo solo exposto, seja pelo transportado pelo escoamento pluvial das áreas asfaltadas.

Os índices de oxigênio dissolvido (OD) e de demanda bioquímica de oxigênio ( $D B O$ ) apresentaram valores elevados nos pontos mais próximos à montante, evidenciando a abundância de oxigênio e de reações químicas e biológicas que ali se estabelecem. Ao contrário disso, os pontos mais à jusante apresentaram valores reduzidos de oxigênio, por causa da concentração de efluentes e do baixo grau de energia desses pontos.

As maiores modificações que dizem respeito a atuação antrópica puderam ser observadas nos índices de coliformes fecais, com valores de até $1.600 .000 \mathrm{NMP} / 100 \mathrm{ml}$, para os três setores. Os valores elevados indicam o alto grau de contaminação do corpo d'água, já que o limite estipulado pelo CONAMA é de até 1.000 $\mathrm{NMP} / 100 \mathrm{ml}$. Da mesma forma, ocorreu para os coliformes totais que também apresentaram valores elevados de até $>1.600 .000$ NMP/100 $\mathrm{ml}$ nos três setores com maior concentração no setor C (PT1) na jusante do canal. Estes valores estão associados aos lançamentos diretos de esgotos domésticos sem qualquer tipo de tratamento, fato que contribui para a degradação do ambiente. 
Rede de drenagem urbana em área tropical: mudanças na morfologia do canal

e níveis de poluição das águas - Rio dos Macacos - Rio de Janeiro - RJ, pp. 39 - 64

Este trabalho faz parte de um projeto voltado para a análise da rede de drenagem da cidade do Rio de Janeiro, com base na continuidade do monitoramento das variáveis hidrodinâmicas do canal, identificando a variação e intensidade das mudanças ocorridas e os níveis de poluição das águas ao longo do tempo.

\section{V- Recomendações}

Tendo em vista as modificações ocorridas na morfologia do canal e os elevados níveis de poluição das águas, sugere-se recomendações que darão continuidade à esta pesquisa, possibilitando a recuperação de parte das características naturais do canal.

a) Continuidade do monitoramento da capacidade do canal, uma vez que o contínuo assoreamento é um dos responsáveis pela ocorrência de cheias e inundações locais.

b) Reabilitação da estação fluviométrica do Jardim Botânico, desativada em julho de 1979, que fornecerá dados relativos à vazão e à velocidade do fluxo.

c) Avaliar a proporcionalidade de tamanho das seções transversais da nascente até a lagoa Rodrigo de Freitas eliminando os estrangulamentos em trechos do canal que favorecem o transbordamento e a erosão das margens em períodos chuvosos. d) Instalação de estações sedimentométricas que registrem o comportamento e a distribuição dos sedimentos ao longo do canal, para que seja possível identificar os processos atuantes, no que se refere ao fornecimento de material para o leito.

e) Reconstituição das áreas marginais ocupadas por casas, principalmente à montante, através da fixação da mata ciliar, importante para promover a estabilidade do canal e a reconstituição do ecossistema.

f) Instalação de estações de monitoramento de qualidade da água com o propósito de identificar os locais mais críticos quanto à poluição. Avaliação da rede de esgoto não só identificando a rede atual como a rede clandestina, promovendo soluções junto aos orgãos públicos.

g) Intensificação do trabalho de conscientização da população, já iniciado pela Secretaria Municipal de Meio Ambiente, sobre a importância da preservação dos ambientes fluviais e do desenvolvimento sustentável.

h) Avaliação do nível de saúde da população local através de pesquisas e entrevistas

Sendo assim, a viabilização de projetos e planos de gestão para áreas degradadas, baseiase em estudos preliminares, havendo porém, a necessidade de disposição e interesse políticos para que finalmente possam ser postos em prática.

\section{Bibliografia}

AMARAL, S. B. Aspectos da Relação entre UsoOcupação do Solo e Qualidade da Água na Bacia do Rio Pequeno - São José dos Pinhais/PR. Dissertação de Mestrado. Curitiba: PPGG/UFPR, 2002, 133p.

BENETTI, A. e BIDONE, F. O Meio Ambiente e os Recursos Hídricos. In: TUCCI, C. E. M. Hidrologia Ciência e Aplicação. 2a Ed. Porto Alegre: Editora da UFRGS, 1997, p.849-875.

BRANCO, S. M e ROCHA, A. A. Poluição, Proteção e Usos Múltiplos de Represas. São Paulo: Edgard Blücher/CETESB, 1977, 185p.
BRANDÃO, A. M. P. (1997). As Chuvas e a Ação Humana: Uma Infeliz Coincidência. In: ROSA, L. P. e LACERDA, W. A. Tormentas Cariocas. Rio de Janeiro: COPPE/UFRJ, 1997, p.21-36.

CLESCERI, L. S., GREENBERG, E. A., e EATON, A. D. Standard Methods: For the Examination of Water and Wastewater. 20 ${ }^{\text {th }}$ Edition. APHA/ AWWA, 1998, (2) p. 8-11, (5) p.3-9.

CONAMA - Conselho Nacional do Meio Ambiente. Resolução № 20. Brasília, 1986.

costA, A. J. Modificações no Comportamento 
Hidrológico de Bacias Hidrográficas no Município do Rio de Janeiro (RJ) em Função da Urbanização. Dissertação de Mestrado. PPGG/ UFRJ , 1995, 133p.

CUNHA, S. B. e GUERRA, A. J. T. Degradação Ambiental. In: CUNHA, S. B. e GUERRA, A. J. T. Geomorfologia e Meio Ambiente. Rio de Janeiro: Bertrand Brasil, 1996, p.337-379.

EBISEMIJU, F. S. The Response of Headwater Stream Channels to Urbanization in the Humid Tropics. Hydrological Process, vol.3. 1989, p.237253.

EMBRAPA. Identificação de Limitações Pedológicas e Ambientais Causadoras de Degradação de Áreas do Jardim Botânico do Rio de Janeiro. Rio de Janeiro: JBRJ, 1992, 101p.

EMBRAPA. Sistema Brasileiro de Classificação de Solos. Centro Nacional de Pesquisa de Solos. Brasília: EMBRAPA Produção de Informação, 1999, 412p.

GRAF, W. L. A Lei da Razão em Geomorfologia Fluvial. Notícia Geomorfológica. vol.18, Campinas: ICH-DEGEOG, 1978, p.57-78.

GRASSHOFF, K.; EHRHARDT, M. e KREMLING, K. Methods of Seawater Analysis. $2^{\text {nd }}$ ed. Verlag Chemie, 1983, $178 \mathrm{p}$.

GREGORY, K. J., DAVIS, R. J. e DOWNS, P. W. Identification of River Channel Change to Due to Urbanization. Applied Geography, vol.12, 1992, p.299-318.

MOTA, S. Introdução à Engenharia Ambiental. Rio de Janeiro: ABES, 1997, 280p.

MUEHE, D. e VALENTINI, E. O Litoral do Estado do Rio de Janeiro: Uma Caracterização FísicoAmbiental. Rio de Janeiro: FEMAR., 1998, 123p.

MURARO, L. G. Caracterização da Qualidade da Água ao Longo do Curso do Rio dos Macacos, Município do Rio de Janeiro, RJ. Monografia de Conclusão de Curso em Oceanografia. Rio de Janeiro: UERJ, 2001, 79p.

PERRONE, A. e BARROSO, G. Avaliação Preliminar do Transporte de Sólidos pelo Córrego Pau Amarelo: Reserva Biológica de Duas Bocas - ES.
In: I Simpósio Nacional de Geomorfologia. Revista Sociedade e Natureza, no 15. Uberlândia: EDUFU, 1996, p.354-358.

PORTO, R., ZAHED Fo, K., TUCCI, C. e BIDONE, F. Drenagem Urbana. In: TUCCI, C. E. M. Hidrologia Ciência e Aplicação. 2âaEd. Porto Alegre: Editora da UFRGS, 1997, p.805-847.

PORTO, M.F.A., BRANCO, S. M., e DE LUCA, S. J. Caracterização da qualidade das águas. In: S. M. BRANCO e R.L.L. Hidrologia Ambiental. Coleção ABRH de Recursos Hídricos. São Paulo: EDUSP, 1991, p.27-68.

Rebello, A. L. R. e CARREIRA. R. Métodos Analíticos de Referência em Oceanografia Química - Programa Revizee. Rio de Janeiro: Ministério do Meio Ambiente, dos Recursos Hídricos e da Amazônia Legal (MMA)/ Secretaria de Coordenação dos Assuntos do Meio Ambiente (SMA), 1997, 75p.

SERLA. Projeto de Contenção de Cheias da Bacia da Lagoa Rodrigo de Freitas. Estudos de Impacto Ambiental (EIA). Rio de Janeiro, 1990, 128p.

SUGUIO, $K$ e BIGARELLA, J. Ambientes Fluviais. 2ªEd. Florianópolis: Editora da UFSC, 1990, 183p.

THORNE, C. R., ALLEN, R. G. e SIMON, A. Geomorphological River Channel Reconnaissance for River Analysis, Engineering and Management. Transactions of the Institute of British Geographers, vol. 21, 1996, p.469-483.

WHITLOW, J. R. e GREGORY, K. J . Changes in Urban Stream Channels in Zimbabwe. Regulated Rivers: Research and Management, vol.4, 1989, p.2742.

WOLMAN, M. G. A Cycle of Sedimentation and Erosion in Urban River Channels. Geografiska Annaler, vol.49, 1967, p.385-395.

Trabalho enviado em julho de 2007 Trabalho aceito em agosto de 2007 